\title{
Causes and Proofs for Removal of a Pastor
}

\author{
by
}

\author{
Jason A. Gray
}

\begin{abstract}
A thesis submitted to the
Faculty of the School of Canon Law of

The Catholic University of America

Washington, D.C.
\end{abstract}

In partial fulfillment of the requirements for the degree Licentiate in Canon Law 
Copyright (C) 2006 by Jason A. Gray

All rights reserved.

www.lulu.com (ID \#327397)

This thesis by Jason A. Gray fulfills the thesis requirement at the Catholic University of America, Washington, D.C., for the licentiate degree in canon law approved by John Beal, J.C.D., as Director, and by Robert Kaslyn, S.J., J.C.D., as Reader.

Other persons are permitted to copy, distribute, or display this work with the following provisions: Reproduction of this work must contain proper attribution to the author. No reproduction of this work is allowed for commercial purposes. This text may not be used to produce a derivative work, whether by altering, transforming, or building on this text.

This thesis is cited as follows: Gray, Jason A., Causes and Proofs for Removal of a Pastor (Peoria, IL: Lulu Press, 2006).

The edition of this thesis in the library of the Catholic University of America is paginated differently and is cited as follows: Gray, Jason A., "The Causes and Proofs in the Removal of a Pastor" (JCL Thesis, The Catholic University of America, 2006).

Other permissions to copy, distribute, display, or reprint this work require the expressed permission of the author.

Father Jason Gray is a priest of the diocese of Peoria who earned his J.C.L. from Catholic University in 2006.

More information about this topic may be found at www.jgray.org. 
Will no one rid me of this troublesome priest?

- Henry II (in reference to Thomas Becket) 



\section{TABLE OF CONTENTS}

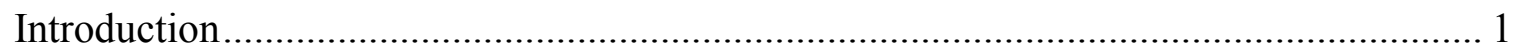

Chapter I: The Standard for Removal in Canon 1740 .................................................. 3

Part A: Exegesis of Canon 1740 .................................................................. 4

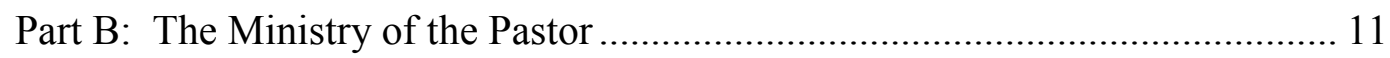

Ministry of the Word (C. $528 \S 1)$..................................................... 12

Ministry of the Sacred Liturgy (Cc. $528 \S 2$ and 530)........................... 13

Ministry of Pastoral Governance (C. 529 §1) ..................................... 15

Ministry of Ecclesiastical Communion (C. 529 §2) ........................... 18

Financial Administration (C. 532) .................................................. 20

Other Causes of a Pastor's Harmful or Ineffective Ministry ................... 22

Chapter II: The Causes for Removal in Canon 1741 ............................................... 25

Detriment or Disturbance to Ecclesiastical Communion (C. 1741, $1^{\circ}$ ) ............... 26

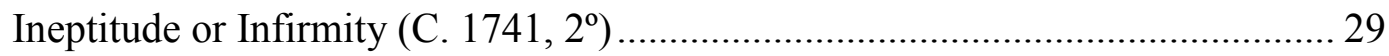

Loss of a Good Reputation or Aversion to the Pastor (C. 1741, $3^{\circ}$ )................... 34

Neglect or Violation of Parochial Duties (C. 1741, $4^{\circ}$ ) ................................... 40

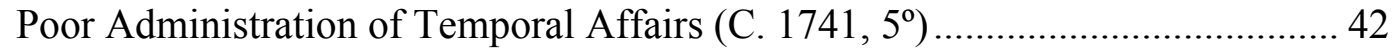

Other Possible Causes............................................................................. 48

Chapter III: The Collection and Evaluation of Proofs ............................................ 51

Part A: The Instruction of a Cause for Removal (C. $1742 \S 1)$........................... 51

The Right of Defense and Right to a Good Name ............................... 55

Part B: The Collection of Proofs......................................................................... 58

The Declarations of the Pastor (Cc. 1530-1538) ................................... 59

Proof through Documents (Cc. 1539-1546)....................................... 61

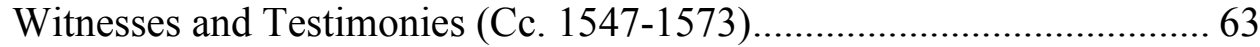

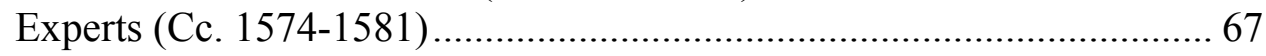

Judicial Examination and Inspection (Cc. 1582-1583)........................ 68

Presumptions (Cc. 1584-1586) .................................................... 69

The Purpose of the Proofs .............................................................. 71

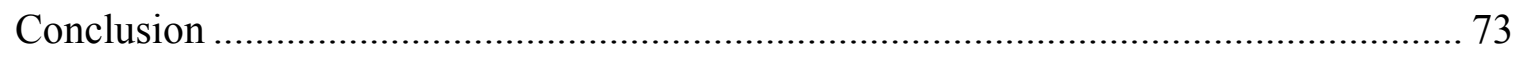

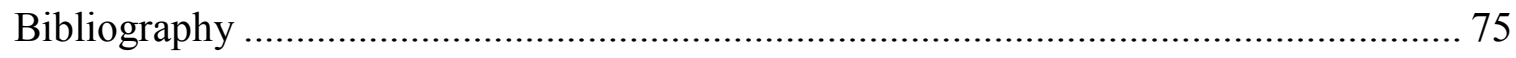





\section{Introduction}

A pastor is generally appointed to serve a parish for an indefinite time and therefore possesses stability in office. Stability allows a pastor to dedicate himself to the service of his parishioners, to guide the faithful entrusted to him, and to promote their spiritual growth. A pastor with stability in office is better able to know his people and to gain their trust. A pastor's stability is a reflection of the enduring bond that joins a pastor to his parishioners in a spiritual relationship. This spiritual relationship is akin to the marriage bond that unites a bridegroom in a spiritual relationship with his bride. As Christ is the bridegroom and the Church is his bride, so a pastor is to represent Christ to his parishioners in a spirit of loving service. ${ }^{1}$ This marital image underscores the kind of dedication that should characterize the ministry of a pastor in his parish.

Unfortunately, the ideal relationship between a pastor and his parish is sometimes absent. A pastor might do harm to the parishioners he is required to help. He might fail to provide them with the ministry they deserve. A pastor's lack of dedication could lead his flock to be suspicious of him rather than trusting of his good will. When the service of a pastor is so detrimental that the faithful suffer, the pastor ceases to be an instrument to draw the faithful closer to Christ. Rather, he becomes an obstacle to that goal. In this adverse situation, a diocesan bishop faces the difficult decision that he may need to remove the pastor from office.

\footnotetext{
${ }^{1}$ Eph. 5:32.
} 
The removal of a pastor is always lamentable, and stands as the last and most severe remedy for a pastor's negative ministry to his parish. The removal of a pastor severs the spiritual bond that should exist between a pastor and his people and can traumatically affect the life of a parish. If the relationship between a pastor and his parishioners can be compared to the marital covenant, the removal of a pastor can have some of the painful characteristics of a separation and divorce. Although the removal of a pastor is traumatic, it may be the only solution to an already difficult situation in which the faithful have suffered grave harm in their parish because of their pastor's ministry. The removal of a pastor is sometimes necessary for the spiritual and pastoral good of all those involved.

This thesis will examine the causes and the proofs in the removal of a pastor as described in canons 1740,1741 , and the first part of $1742 \S 1$. The first chapter will consider the standard that must be met for the removal of the pastor as defined in canon 1740. The removal of a pastor depends on his ministry, and so the first chapter will also consider the essential elements of a pastor's ministry as described in canons 528-530 and 532. The second chapter will consider the list of possible causes in canon 1741 that are sufficient for the removal of the pastor. The third chapter will consider the investigation into the pastor's ministry as described in canon $1742 \S 1$. Since the investigation into the pastor's ministry will involve the collection of proofs, the third chapter will also consider the types of proofs that might be collected in light of canons 1526-1586. A careful study of the legal principles that govern the removal of a pastor will help this procedure to be used prudently, judiciously, and effectively. 


\section{Chapter I: The Standard for Removal in Canon 1740}

This chapter will consider canon 1740 and the fundamental standard which must be met for the removal of any pastor: the pastor's ministry is demonstrated to be harmful or ineffective. In the second chapter, the five causes for removal in canon 1741 will be presented as examples of circumstances that might lead to the removal of a pastor. Each of these circumstances can render a pastor's ministry harmful or ineffective according to the standard of canon 1740. Although several detailed causes are listed in canon 1741, a pastor's detrimental ministry remains the basis for his

removal. And therefore, the provisions of canon 1740 and its standard for removal ultimately control this procedure.

The first part of this chapter will consider the standard for removal presented in canon 1740. As the removal of a pastor is justified only when his ministry is harmful or ineffective, the second part of this chapter will consider the essential elements of a pastor's ministry. The examination of these essential elements is helpful because the deficiencies in a pastor's ministry will be more clearly identified in light of the ideal ministry a pastor is to provide. 


\section{Part A: Exegesis of Canon 1740}

Canon 1740 states the general standard to be used when deciding whether to remove a pastor:

When the ministry of any pastor becomes harmful or at least ineffective for any cause, even through no grave personal negligence, the diocesan bishop can remove him from the parish. ${ }^{2}$

The focus in the procedure of the removal of a pastor is not on the person of the pastor but on the ministry (ministerium) that the pastor provides. The pastor's ministry consists of governing his parish, exercising pastoral care, and attending to the good of the faithful entrusted to him. The pastor is to be a shepherd of souls who shares in the ministry of Christ, the Good Shepherd. ${ }^{3}$ As a shepherd, the ministry of the pastor is ordered toward the service of the people of God. The pastor's ministry to his parishioners binds them together in a mutual relationship: The pastor has the obligation to provide this ministry to the faithful, just as the faithful have the right to receive spiritual assistance from their pastor. ${ }^{4}$ Nevertheless, a pastor might not live up to his obligation, which would cause the faithful to suffer as they would be deprived of their right to spiritual assistance. The law governing a pastor's removal provides a pastoral remedy that protects the rights of the faithful and consequently

\footnotetext{
${ }^{2}$ Codex Iuris Canonici auctoritate Ioannis Pauli PP. II promulgatus (Vatican City: Libreria Editrice Vaticana, 1983) c. 1740: "Cum alicuius parochi ministerium ob aliquam causam, etiam citra gravem ipsius culpam, noxium aut saltem inefficax evadat, potest ipse ab Episcopo dioecesano a paroecia amoveri." English translation from Code of Canon Law, Latin-English Edition: New English Translation (Washington, DC: CLSA, 1998). All English translations of canons from this code are taken from this source unless otherwise indicated.

${ }^{3}$ C. 519. Francesco Coccopalmerio, "De Causis ad Amotionem Parochorum Requisitis," Periodica 75 (1986) 276.

${ }^{4}$ C. 213. Ángel Marzoa, "Sectio II: De procedura in parochis amovendis vel transferendis (cc. 17401752)" in Exegetical Commentary on the Code of Canon Law, ed. Ángel Marzoa et al. (Chicago: Midwest Theological Forum, 2004) IV/2:2112.
} 
looks to the good of souls. ${ }^{5}$ In 1910 , the Sacred Congregation of the Consistory established a non-penal procedure for the removal of a pastor in its decree, Maxima Cura. The preface of this decree emphasized the good of souls in the ministry of the pastor:

The salvation of the people is indeed the supreme law: and the ministry of the pastor was instituted in the Church not for the benefit of the one to whom it is entrusted, but for the salvation of those for whom it is conferred. ${ }^{6}$

When deciding whether a pastor should be removed, the diocesan bishop rightly keeps before his eyes the good of souls and the protection of the rights of the faithful. $^{7}$

A pastor may be removed when his ministry becomes harmful or at least ineffective (noxium aut saltem inefficax evadat). A pastor's ministry is noxius when he does harm or acts in an affirmative way that injures the rights of the faithful. A pastor's ministry is inefficax when he does not do a necessary good or when he fails to fulfill a duty that he is obligated to provide for the faithful. ${ }^{8}$ For example, a pastor's ministry is harmful if his preaching contains doctrinal error. Conversely, a pastor's ministry is ineffective if his vacuous preaching lacks all spiritual content. As the pastor's removal hinges on his ministry which is noxius or inefficax, a cause and effect relationship must exist between the negative aspect of the pastor's ministry and

\footnotetext{
${ }^{5}$ Coccopalmerio, De Causis, 276. Zenon Grocholewski, "Trasferimento e rimozione del parroco" in La Parrocchia, Studi Giuridici, vol. 43 (Vatican City: Libreria Editrice Vaticana, 1997) 213.

${ }^{6}$ Sacred Congregation of the Consistory, Decree Maxima Cura preface, 20 August 1910, AAS 2 (1910) 636: "Salus enim populi suprema lex est: et parochi ministerium fuit in Ecclesia institutum, non in commodum eius cui committitur, sed in eorum salutem pro quibus confertur." All translations not taken from the Code of Canon Law are provided by the author of this thesis unless otherwise noted.

${ }^{7}$ C. 1752.

${ }^{8}$ Coccopalmerio, De Causis, 276. Grocholewski, 214.
} 
the detrimental effect on the people of God. The pastor's ministry must either positively or negatively result in some damage to the faithful. The adverb saltem implies that a pastor's ministry may appear to be more detrimental when he does actual harm (noxius) than when he simply fails to do good (inefficax). Nevertheless, the pastor may still be removed from office even when his ministry is deemed merely ineffective.

The pastor's ministry is affected in its totality if every essential aspect of his pastoral duties is rendered harmful or ineffective. The pastor's ministry is affected in part if only one area is harmful or ineffective while his ministry is otherwise sufficient or even praiseworthy. The diocesan bishop may remove a pastor whose ministry is negative only in part, provided that the negative aspect of the pastor's ministry is in an area of greater importance. ${ }^{9}$ For example, one pastor may preach well but be unable to administer the parish finances competently. Another pastor may be a good shepherd of his parish when he is present, but his illegitimate absence from his parish may cause his ministry to suffer. Alternatively, a third pastor may be unable to sing. While the first two pastors may be removed because their ministry is deficient in an essential aspect, the last pastor should not be removed because singing is not essential to his pastoral ministry.

A pastor can be removed for any cause (ob aliquam causam). There is fundamentally only one cause sufficient for the removal of a pastor: that his ministry is harmful or at least ineffective. Even so, the code does not limit the types of causes

\footnotetext{
${ }^{9}$ Coccopalmerio, De Causis, 277. The areas of greater importance referred to by Coccopalmerio should be understood as those elements which are essential to a pastor's ministry. These essential elements will be discussed in the second part of this chapter.
} 
that can generate this negative ministry. Many factors may affect the ability of a pastor to meet his obligations. Yet, the removal of a pastor depends primarily on his detrimental ministry and secondarily on the cause by which his ministry has suffered. A pastor may be removed for any cause provided that it leads to his harmful or ineffective ministry.

Although the causes for removal are unrestricted, canon 1741 gives a list of five causae that are sufficient for removal. These five causes will be thoroughly addressed in chapter two. The list in canon 1741 is understood to be illustrative and not taxative, not only because canon 1740 permits removal ob aliquam causam, but also because canon 1741 states that "the causes . . . are especially the following." 10 The use of "especially" (praesertim) indicates that other causes beyond those mentioned in canon 1741 can be used for the removal of a pastor. In spite of the great variety among these five causes, they share the common characteristic that they can render a pastor's ministry harmful or ineffective.

In the jurisprudence of the Apostolic Signatura, a cause that has rendered the pastor's ministry harmful or ineffective is sufficient for removal if it has three characteristics: The cause must be grave, lasting, and proven. ${ }^{11}$

First, the cause must be grave. A grave cause is one in which the diocesan bishop judges that the removal of the pastor is necessary for the good of souls. A diocesan bishop weighs the gravity of a cause in light of its impact on the ministry of

\footnotetext{
${ }^{10}$ C. 1741: "Causae ... hae praesertim sunt." This list would be understood to be taxative if the canon indicated that only these five causes can be considered for removal. See Coccopalmerio, De Causis, 275.

${ }^{11}$ Frans Daneels, "The Removal or Transfer of a Pastor in the Light of the Jurisprudence of the Apostolic Signatura," Forum 8:2 (1997) 296.
} 
the pastor and the faithful whom the pastor is bound to serve. A merely just cause in which the diocesan bishop considers the removal to be prudent or beneficial is insufficient. A grave cause is required to remove anyone stably appointed to an office for an indeterminate period of time. As a pastor possesses stability in office, the law itself requires a grave cause for his removal. ${ }^{12}$ Although the cause for the pastor's removal may arise from a variety of circumstances, the cause must always be grave for removal to be justified. Therefore, the use of aliquis in canon 1740 permits causes of various types, but not causes of lesser gravity.

Second, the cause for removal must be lasting. A lasting cause is one that endures for a time, but it need not be permanent. However, a temporary cause is one that will likely cease in a brief time and is insufficient for removal. ${ }^{13}$ The diocesan bishop must judge whether the cause has sufficient longevity to render a pastor's ministry gravely harmful or ineffective, thus justifying the removal of the pastor.

Third, the cause must be proven. A cause is proven through objective and demonstrable evidence, but not by means of rumor or subjective opinion. The cause is proven through the investigation of the pastor's ministry which will be addressed in the third chapter. The results of this investigation must be evaluated by the diocesan bishop to determine if there is sufficient evidence to justify removal.

No pastor fulfills the many duties of his office perfectly, and human weakness will always render some aspects of a pastor's ministry insufficient. Yet, it would be

\footnotetext{
${ }^{12}$ Cc. $193 \S \S 1$ and 2, and 522.

${ }^{13}$ Coccopalmerio, De Causis, 277. The causes for removal listed in canon 1741 have different standards with respect to the duration of the cause. For example, a mental or physical infirmity should be permanent to justify removal (c. $1741,2^{\circ}$ ). However, an aversion to the pastor on the part of his parishioners must only be foreseen not to cease in a brief time (c. $\left.1741,3^{\circ}\right)$.
} 
an injustice to remove a pastor for any fault whatsoever, no matter how insignificant. A pastor's minor fault should not be considered sufficient for removal, even if it does lead to some measure of harm or some lack of effectiveness in his ministry. The cause must be sufficiently serious that the pastor's ministry is impaired in a fundamental way. ${ }^{14}$ If a pastor's preaching is considered as the basis for his removal, the cause is grave if he preached doctrinal error, but not if he began a homily with a distasteful joke. The cause is lasting if his preaching was routinely harmful or ineffective, but not if he gave only one poor homily. The cause is proven if it is supported by evidence, but not if it is simply alleged.

While there may be several possible causes for the removal of a pastor in a specific case, at least one cause must be grave, lasting, and proven. The following response of the Apostolic Signatura emphasizes this point:

Even if all the causes [for the removal of a pastor] are not certain, [X.] thinks that, from their sum, the Ordinary can form the conclusion that there exists a juridically sufficient cause. This is true only if at least one cause is juridically valid and certain: from the accumulation of probability one cannot in fact arrive at certainty. ${ }^{15}$

Therefore, even if there are several causes for removal, at least one of them must be sufficient to warrant the removal of a pastor.

A pastor can be removed if his ministry has suffered, even through no fault of his own (etiam citra gravem ipsius culpam). The removal of a pastor from office is distinguished from the punishment of a pastor for a delict. The punishment of a delict

\footnotetext{
${ }^{14}$ Grocholewski, 214.

${ }^{15}$ Grocholewski, 216, footnote 60: "[X] pensa che anche se tutte le cause non sono certe, da tutto l'insieme l'Ordinario possa formarsi il concetto dell'esistenza di una causa giuridicamente sufficiente. Questo è vero solo se almeno una causa è giuridicamente valida e certa: da un cumulo di probabilità infatti non si genera la certezza (excerpt from a letter of the Apostolic Signatura to the Secretary of State, Prot. N. 9036/77 CA, 24 July 1978).”
} 
requires that the offender be imputable by reason of malice (dolus) or fault (culpa). ${ }^{16}$ Similarly, a pastor's harmful or ineffective ministry may arise by reason of the pastor's own malicious actions or his culpable negligence. However, unlike in a penal process, a pastor's ministry may also be rendered harmful or ineffective through no fault of the pastor whatsoever. While there must be a grave cause to justify the removal of a pastor from office, there is no need to demonstrate grave culpability on the part of the pastor. ${ }^{17}$ Therefore, a pastor may be removed for a grave cause, even if the culpability of the pastor is light or even non-existent. For example, a pastor whose ministry is ineffective because of senility is not at fault for his condition, even though his condition may cause grave harm to his people through his inadequate ministry. ${ }^{18}$

The removal of a pastor is not a penal act. Rather, the procedure for removal provides for the needs of the faithful and the good of souls which have been negatively affected by the ministry of the pastor. ${ }^{19}$ For this reason, removal is described not as a penal remedy, but as a pastoral remedy. ${ }^{20}$ The importance of this pastoral focus of the law is reflected in the last canon of this section of the code

\footnotetext{
${ }^{16}$ C. $1321 \S 1$.

${ }^{17}$ Grocholewski, 215. Canon 193 requires a grave cause (ob graves causas) for the removal of a pastor, although canon 1740 does not require that the pastor be gravely at fault (citra gravem culpam).

${ }^{18}$ Coccopalmerio, De Causis, 277.

${ }^{19}$ Coccopalmerio, De Causis, 299. Marzoa, 2109. Daneels indicates that a crime can serve as a cause for the removal of the pastor, provided that the diocesan bishop seeks not to punish a crime but to make provision for the good of souls. In this case, the procedure does not seek to prove the imputability of the pastor for a delict, but the harm done to the faithful. See Daneels, 296.

${ }^{20}$ Coccopalmerio, De Causis, 278. Florentius Romita, "De Parochorum Amotione, Translatione et Renuntiatione juxta Vaticanum II," Monitor Ecclesiasticus 94 (1969) 433. Romita notes that the procedure for removal is administrative in as much as it arises from ecclesiastical authority. It is pastoral in as much as it tends solely and directly to the good of souls. It is juridic in as much as it is governed by legal norms. It is also paternal in as much as the diocesan bishop is bound to guard and protect the rights of human persons, both the rights of his pastor and the rights of his faithful.
} 
which states that the salvation of souls is the supreme law in the Church. ${ }^{21}$ The good of souls takes precedence over the stability of the pastor in office when these two values come into direct conflict.

\section{Part B: The Ministry of the Pastor}

Every case of removal is based on some form of harmful or ineffective ministry. A pastor may be removed because, in some way, he has seriously failed to provide the pastoral service that he owes to his people. The definition of what makes a pastor's ministry harmful or ineffective is best understood in light of the essential elements of his ministry. A pastor has many responsibilities that are addressed in various parts of the code, though some of these responsibilities are more essential to a pastor's ministry than others. ${ }^{22}$ The remainder of this chapter will consider those responsibilities in canons 528-530 and 532 at the core of a pastor's mission and which are a sine qua non for his successful ministry. ${ }^{23}$ A pastor's ministry becomes harmful

\footnotetext{
${ }^{21}$ C. 1752.

${ }^{22}$ Canons 519-538 contain obligations for pastors, while canons 273-289 contain obligations common to all clerics. A pastor is also bound by the obligations to teach and instruct the faithful expressed in book three of the code, and by the obligations to sanctify the faithful through the celebration of the sacraments expressed in book four of the code. Furthermore, the canons of book five of the code bind pastors as the administrators of the temporal goods of their parishes. For a more thorough treatment on the obligations of a pastor, see Edward A. Sweeney, The Obligations and Rights of the Pastor of a Parish: according to the Code of Canon Law (Ottawa: Alba House, 2002); Marcello Morgante, La Parrocchia nel Codice del Diritto Canonico: Commento giuridico-pastorale (Milan: Edizione Pauline, 1985); or Francesco Coccopalmerio, De Paroecia, (Rome: Pontificia Università Gregoriana, 1991).

${ }^{23}$ Coccopalmerio cites canons 519, 528-530 and 534 as essential to a pastor's ministry. See Coccopalmerio, De Paroecia, 61. Parizek cites canons 519, 521, 528-530, and 535 as central to a pastor's ministry. See James F. Parizek, "Section II: Procedure in Removal and Transfer of Pastors (cc. 1740-1752)" in The Code of Canon Law: A Text and Commentary (hereafter Text and Commentary), ed. James A. Coriden et al. (New York/Mahwah, NJ: Paulist Press, 1985) 1036 and 1039. Janicki cites canons 528-530 as the primary duties of a pastor. See Joseph A. Janicki, "Chapter VI: Parishes, Pastors, and Parochial Vicars (cc. 515-552)" in Text and Commentary, ed. James A. Coriden et al., 420. Other commentators refrain from singling out individual canons of particular importance.
} 
or ineffective when one of its essential elements has been compromised. The pastor may be removed when his failure in one of the essential elements of his ministry results in some grave harm to his parish.

\section{Ministry of the Word (C. $528 \S 1)$}

A pastor is responsible for carrying out the functions of teaching, sanctifying, and governing for his parish. ${ }^{24}$ As an expression of the first of these functions, canon $528 \S 1$ obligates the pastor to proclaim the word of God, and to insure that the faithful are accurately instructed in the truths of the faith. As a part of this function, the pastor must foster spiritual works, support social justice, care for the education of children, and reach out to those who have fallen away from the faith and those who are not Catholic. These obligations are aspects of the fundamental duty that binds especially pastors to proclaim the gospel. ${ }^{25}$

According to canon $528 \S 1$, the pastor fulfills this ministry of the word by two primary means: giving a homily on Sundays and holy days of obligation, and offering catechetical instruction. These two means are also treated in the first title of book three of the code on the ministry of the divine word which is divided into two chapters: preaching and catechetical instruction. ${ }^{26}$ Among all the forms of preaching, the homily is preeminent and holds a place of importance in the proclamation of the

The importance of canons 528-530 is commonly recognized among scholars. This author has also chosen to treat canon 532 because of its important connection with financial administration (see c. $\left.1741,5^{\circ}\right)$. Canon 519 defines those the pastor is bound to care for and will be treated within the context of canon $529 \S 1$ which describes the ministry of pastoral governance. Canons 534 (regarding the Mass to be offered for the people) and 535 (regarding recordkeeping) will not be treated as they are not likely to serve as a basis for the removal of the pastor.

\footnotetext{
${ }^{24}$ C. 519.

${ }^{25}$ C. 757. Coccopalmerio, De Paroecia, 66 and 69-70.

${ }^{26}$ See cc. 756-780. Coccopalmerio, De Paroecia, 72.
} 
essential mysteries of the faith. ${ }^{27}$ A pastor must also take care that all those in his parish receive suitable catechesis, especially in preparation for the sacraments. ${ }^{28}$ Therefore, the preaching of the homily and the catechetical formation of his parishioners are two essential and indispensable elements of a pastor's ministry of the word.

A pastor's ministry becomes harmful or ineffective if he is gravely deficient in either his preaching of the homily or his catechetical formation of his parishioners. A pastor's homilies may render his ministry harmful if he preaches false doctrine, leads the people into serious doubt, or offends the sensibilities of the faithful by his crudeness. A pastor might also do harm by actively advocating political candidates for partisan reasons. ${ }^{29}$ A pastor's ministry may be ineffective if he regularly omits the homily on Sundays, or delivers listless homilies devoid of spiritual value. A pastor may also be ineffective if he cannot speak the language of the people or cannot be understood because he mumbles or has a speech impediment. The pastor's ministry would also be deficient if he fails to make adequate provision for the catechesis of children, for those preparing for the sacraments, or for converts who wish to undergo instruction in preparation for joining the Church.

\section{Ministry of the Sacred Liturgy (Cc. $528 \$ 2$ and 530)}

The second function of sanctifying the people of God is expressed in canon $528 \S 2$ which obligates the pastor to assist the faithful through the celebration of the

\footnotetext{
${ }^{27}$ Cc. $767-769$.

${ }^{28}$ Cc. 773,776 , and 777.

${ }^{29}$ C. $287 \S 2$. Clerics are not to have an active part in political parties unless the competent authority judges that the protection of the rights of the Church or the promotion of the common good is at stake.
} 
sacraments. The pastor is to make the Eucharist the center of parish life, nourish the faithful through the celebration of the sacraments, encourage frequent reception of the Eucharist and penance, promote family prayer, and encourage active participation in the liturgy while guarding against abuse. ${ }^{30}$ Some of the most important sacramental functions in the life of a parish are singled out as especially (specialiter) entrusted to the pastor by canon 530. These functions include the celebration of baptism, confirmation in danger of death, viaticum, marriage, funeral rites, special blessings, and solemn Masses. While the pastor is not prevented from delegating other qualified ministers to assist him in his sacramental ministry, the pastor retains the obligation of ensuring that the sacramental needs of his parishioners are met. As part of his obligation, the pastor is not to deny the sacraments to those who seek them at appropriate times unless the person is not properly disposed or prohibited by law. ${ }^{31}$ Book four of the code refers to other obligations of the pastor in the celebration of individual sacraments. ${ }^{32}$

A pastor's sacramental ministry may be detrimental for several reasons. A pastor's ministry is harmful if he celebrates invalid sacraments, or if he scandalizes the faithful through violations of liturgical law. For example, a pastor might celebrate an invalid marriage of two persons whom he knows are not free to marry in the

\footnotetext{
${ }^{30}$ Coccopalmerio, De Paroecia, 82.

${ }^{31}$ C. 843 §1. Coccopalmerio, De Paroecia, 85.

${ }^{32}$ There are many obligations imposed on a pastor in book four of the code. For example, a pastor is obliged to carefully secure the key to the tabernacle (c. 938 §5). A pastor is obligated to assist a couple preparing for marriage and must diligently complete the pre-marital investigation (cc. 1063, $2^{\circ}$ and 1067). A pastor is also to protect the cleanliness and beauty of the parish church and is to securely protect the parish's sacred goods (c. 1220).
} 
Church. $^{33}$ A pastor might concelebrate Mass with non-Catholic ministers, or might promote the regular distribution of the Eucharist to non-Catholics. ${ }^{34}$ A pastor might do harm to souls if he is unnecessarily rigorous or unconsciously lax with penitents in the confessional. ${ }^{35}$ A pastor's ministry is ineffective if he fails to provide suitable access to the sacraments. For example, a pastor might cancel Sunday Mass without making provision for the faithful. ${ }^{36}$ A pastor might fail to offer adequate opportunities for confession. ${ }^{37}$ A pastor might fail to provide the sacraments of viaticum and anointing of the sick for the dying. ${ }^{38}$

\section{Ministry of Pastoral Governance (C. 529 §1)}

After the code addressed the teaching and sanctifying function of the pastor in canon 528, a treatment of the third function of governing is expected. Canon $529 \S 1$ addresses the governance of a parish, although from the perspective of pastoral charity. A pastor is obligated to visit his people, share their griefs, help the sick, seek out the poor, and support spouses and parents in their family life. These responsibilities go to the heart of what it means to be a pastor and to be a "father" to his people. A pastor is to shepherd those under his care with a loving and gentle

${ }^{33}$ C. 1066 .

${ }^{34}$ Cc. 908 and $844 \S 4$. It is licit to distribute the Eucharist to non-Catholics under the conditions specified in canon $844 \S 4$.

${ }^{35}$ Cc. 978-981. A diocesan bishop must proceed cautiously with a cause for removal on the basis of the pastor's ministry within the confessional because the seal of confession will prevent the pastor from defending his ministry. Regarding the caution to be used when investigating matters protected by the seal of confession, see John Paul II, Apostolic Letter Sacramentorum Sanctitatis Tutela, Art. 20, 30 April 2001, AAS 93 (2001) 737-739.

${ }^{36}$ Canon $533 \S 3$ permits particular law to establish norms that see to the pastoral care of a parish when the pastor is absent.

${ }^{37}$ According to canon $961 \S 1,2^{\circ}$, it is not legitimate to have recourse to general absolution if the presence of a large number of penitents on a single occasion is the result of the pastor's failure to provide adequate opportunities for confession on a regular basis.

\footnotetext{
${ }^{38}$ Cc. $911 \S 1$ and 1001.
} 
hand, just as a father loves and nourishes his children. While this model of governing through service may initially be unexpected, the function of governing (munus regendi) in the Church can never be exercised apart from a Christian model of service. $^{39}$

As a consequence of his duty of pastoral governance, the pastor is obligated to provide comprehensive pastoral care to the entire community of persons entrusted to him. $^{40}$ Because most parishes are territorial, a pastor is generally bound to provide pastoral care to all those within the territorial boundaries of his parish. In some cases, however, a parish may be established for a particular group of the faithful, such as those of a particular rite, language, or nationality. In such a case, a pastor is bound to provide pastoral care for that corresponding portion of the people of God within a certain region. $^{41}$ This duty is analogous to the obligation of a diocesan bishop who is to care for all the Christian faithful in his territory regardless of age, condition or nationality. ${ }^{42}$ A pastor accepts this obligation and is bound by it from the moment he takes possession of his parish. ${ }^{43}$

As a second consequence of his duty of pastoral governance, the pastor is obligated to reside in a rectory near his church, and may be away from the parish on

\footnotetext{
${ }^{39}$ Vatican Council II, Dogmatic Constitution Lumen Gentium 27, 21 November 1964, AAS 62 (1965) 32 (hereafter $L G$ ). The governance of a pastor may be compared to that of bishops who are called to govern their dioceses in the example of the Good Shepherd who came not to be served, but to serve.

${ }^{40}$ C. 519.

${ }^{41}$ Cc. $515 \S 1$ and 518 .

${ }^{42}$ C. 383 §1. See also c. 518 .

${ }^{43}$ C. $527 \S 1$.
} 
vacation only for a limited time. ${ }^{44}$ The obligation of residence is a natural corollary to the pastor's other responsibilities, because the pastor will not be able to meet the needs of his parishioners if he does not live near them. Similarly, a pastor who is absent from his parish too frequently will not be able to minister adequately to his parishioners.

A pastor's ministry may be harmful or ineffective if he fails in his pastoral duties to his parishioners. A pastor's ministry is harmful if he refuses to provide pastoral care or rejects those he is bound to care for. For example, a pastor might behave in an antagonistic manner or might spurn those who seek his help. A pastor's ministry is ineffective if he fails to know his people or provide adequate pastoral care. For example, a pastor might fail to care for his people because of his illegitimate absence from his parish. A pastor might fail to provide ministry to a portion of his parishioners, such as those of a particular racial or ethnic group, perhaps because he cannot speak their language. A pastor might fail to care for the elderly if he does not visit those in nursing homes or hospitals within his parish boundaries. A pastor might fail to care for the sick if he does not respond to emergency sick calls. A negative reaction to the pastor in a parish may be a sign that the pastor's inadequate ministry has caused him to lose the trust and confidence of his people.

\footnotetext{
${ }^{44}$ C. 533. A pastor is permitted to be absent from his parish for up to one month per year, not counting time spent on retreat.
} 


\section{Ministry of Ecclesiastical Communion (C. 529 §)}

Canon $529 \S 2$ obligates a pastor to recognize and promote the mission of the laity, and to work with his bishop and the priests of his diocese. ${ }^{45}$ He must foster among the faithful a concern for parochial communion and an awareness of their place within their diocese and the universal Church. This canon, which has no corresponding canon in the 1917 code, reflects the emphasis on the ecclesiology of communion in the teachings of the Second Vatican Council. ${ }^{46}$ Although the code does not define communion, it is helpful to consider the description of communion in Lumen Gentium. Communion is a relationship that exists among all members of the Church. "All the faithful scattered throughout the world are in communion with each other in the Holy Spirit." ${ }^{\text {47 }}$ This general and universal communion that exists among all members of the Body of Christ can be referred to as ecclesiastical communion (communio ecclesiastica). ${ }^{48}$ The pastor promotes horizontal communion through which the faithful see themselves as united with one another in their parish and with Christians throughout the world. The pastor also promotes vertical communion through which the faithful recognize the leadership of their diocesan bishop and the Holy Father. ${ }^{49}$ Furthermore, the code describes full communion, which requires that the faithful be united with the Church through the bonds of the profession of faith, the

\footnotetext{
${ }^{45}$ Coccopalmerio cites canons 204 and $208-231$ as expressions of the mission of the laity. See Coccopalmerio, De Paroecia, 89.

${ }^{46}$ Parizek, 1037.

${ }^{47} L G$ 13, AAS 17: "Cuncti enim per orbem sparsi fideles cum ceteris in Spiritu Sancto communicant."

${ }^{48}$ Canons 96 and 840 give examples of communio ecclesiastica in which all the faithful are united by the grace of baptism or by the other sacraments.

${ }^{49} L G 32$.
} 
sacraments, and ecclesiastical governance. ${ }^{50}$ The pastor is obligated to promote these triple bonds of communion among his people, just as his people are obligated to maintain their communion with the Church. ${ }^{51}$

A pastor's ministry may harm communion if he injures the rights of the faithful in the Church. For example, a pastor might sow discord or division among his parishioners, or he might impose his own personal opinions with a spirit of authoritarianism, intolerance, or inflexibility. A pastor's ministry may be ineffective in promoting communion if he neglects the rights of the faithful. For example, a pastor might refuse to cooperate in a pastoral endeavor with his own bishop and his brother priests with some harm coming to his parishioners because of his intransigence. A pastor's ministry may be harmful or ineffective with respect to the triple bonds of communion if his witness contradicts one of these bonds to the detriment of the faithful. For example, a pastor might disturb the bond of faith if he publicly questions the magisterium, dissents from definitive teachings on faith or morals in his published writings, or supports movements opposed to Catholic doctrine. A pastor might disturb the bond of the sacraments if he denies the importance of individual sacraments by his words or actions, teaches that any Christian service is equivalent to Sunday Mass, or questions the validity of the Novus Ordo Mass in order to promote the Tridentine Mass. A pastor might disturb the bond

\footnotetext{
${ }^{50}$ C. 205.

${ }^{51}$ C. $209 \S 1$.
} 
of governance if he publicly refuses to submit to the authority of the diocesan bishop or the Holy Father through his disregard of universal or particular law. ${ }^{52}$

\section{Financial Administration (C. 532)}

In virtue of canon 532, a pastor represents his parish in all juridic affairs and is responsible for the correct administration of the temporal goods of his parish. The pastor's care for the assets of his parish is essential to his ministry, because these resources allow the parish to continue to fulfill its mission and to serve its parishioners. The assets of a parish are used to pay for the needs of divine worship, the support of the clergy and ministers, and works of the apostolate and of charity. ${ }^{53}$

Many important financial obligations of the pastor are found in book five of the code. In particular, a pastor has the obligation to care diligently for those offerings given to his parish. He must place the voluntary contributions of the faithful in the parochial account, show respect for the intentions of the donors, and keep a careful record of offerings for Mass intentions. ${ }^{54}$ He has a responsibility to safeguard parish property by his own vigilance, by means of insurance policies, and through the careful observance of canon and civil law. He must ensure that income is protected, debts are paid, and surplus funds are invested with the consent of the ordinary. He is obligated to keep careful books, safeguard archived reports, and

\footnotetext{
${ }^{52}$ Marzoa, 2113.

${ }^{53}$ C. 1254 §2. Any juridic person, including a parish, is not to be established unless it can be foreseen that it will have the resources necessary to fulfill its mission (see c. $114 \S 3$ ).

${ }^{54}$ Cc. $531,958 \S 1$, and $1267 \S \S 1$ and 3 .
} 
report on his administration to the local ordinary and to his parishioners according to the norms of particular law. ${ }^{55}$

The diocesan bishop has an important role in the oversight of the financial management of a parish. The diocesan bishop has the right to issue particular laws or instructions that regulate the administration of ecclesiastical goods, and he has the right to intervene if the pastor is negligent in his administration. ${ }^{56}$ The diocesan bishop determines the limits of the pastor's ordinary administration through parish statutes or particular law. A pastor may not validly place acts of extraordinary administration without a written faculty from the ordinary, nor may he alienate parish property except in accord with the norm of law. A pastor may be held accountable for the financial consequences of an invalid act of administration if the parish suffered illegitimate harm. ${ }^{57}$

A pastor's ministry is negatively affected if he poorly administrates the temporal goods of his parish. A pastor might directly harm the parish by embezzling funds or spending the assets of a parish on something inconsistent with the mission of the Church, such as making large parish contributions to a political candidate. A pastor might make imprudent decisions that imperil the parish finances by frivolously purchasing too many expensive objects for the parish church. A pastor might spend money on needed things, but purchase items of such poor quality that the parish is consequentially harmed. A pastor might be negligent and ineffective if he fails to promote adequate revenue or fails to protect the assets of the parish. A pastor might

\footnotetext{
${ }^{55}$ Cc. $1284 \S 2$ and 1287.

${ }^{56}$ Cc. 392 §2, 1276 §2, and 1279 §1.

${ }^{57}$ Cc. $1281 \S \S 1$ and 3, and 1291-1295.
} 
be negligent in safeguarding the parish resources by squandering the assets of the parish on unsound investments, or by neglecting to take out insurance that should prudently be obtained. A pastor's negligence could violate civil law if he failed to report the salaries of his staff to the Internal Revenue Service, or if he violated important labor laws. ${ }^{58}$ These violations might cause the parish to be subject to a fine or even to litigation. A pastor's negligence might violate canon law if he failed to observe a requirement of book five of the code, such as illegitimately alienating property without a written faculty. Even if the pastor obeys the requirements of book five of the code, he might make large and imprudent (though well-intentioned) contributions to a noble charity, thereby depriving the parish of sufficient assets to continue its mission.

\section{Other Causes of a Pastor's Harmful or Ineffective Ministry}

Canons 528-530 and 532 touch on the most important aspects of a pastor's ministry. If a pastor's ministry suffers in one of these areas, he may be removed from office. A cause for removal, however, may focus on some element of a pastor's ministry other than those mentioned above. In fact, any cause that renders a pastor's ministry gravely harmful or ineffective can form the basis for his removal.

A pastor's ministry may suffer if he fails to meet other obligations that are proper to the clerical state. While these obligations are common to all clerics, a pastor who violates one of his clerical obligations may lose his credibility as a representative of the Church, thus rendering ineffective his ministry and leadership in his parish. For example, a pastor might be known to have violated his promise of

\footnotetext{
${ }^{58}$ C. $1286,1^{\text {o }}$.
} 
celibacy, or might have an intimate friendship with another person which causes scandal among the faithful. Although clerics are to foster simplicity of life, a pastor might develop a reputation for extreme materialism. Although clerics are to wear appropriate ecclesiastical garb in accord with legitimate custom, a pastor might frequently wear inappropriate attire that upsets the faithful. A pastor might behave in a way that is unbecoming to the clerical state by frequently gambling with large sums of money, attending inappropriate or sordid performances, or the like. A pastor's actions may appear incongruous with his state in life if he were to routinely carry a handgun on his person, practice hypnotherapy when counseling his parishioners, or engage in other questionable activities. ${ }^{59}$

Although there are many possible causes that would lead to the removal of a pastor, the specific cause must be grave, lasting, and proven, and must render the pastor's ministry harmful or ineffective, either totally or at least in some essential aspect. The removal of the pastor is justified, not as a punishment for some fault on the part of the pastor, but because his deficient ministry has resulted in some harm to the faithful who have a right to receive benefit from the spiritual goods of the Church. In this light, every removal is motivated ultimately by the desire to care for the good of souls.

\footnotetext{
${ }^{59}$ See cc. 277, 282, 284, and 285.
} 



\section{Chapter II: The Causes for Removal in Canon 1741}

The first chapter considered canon 1740 and the fundamental standard that a pastor can be removed if his ministry has become harmful or ineffective. While this is the only standard for the removal of a pastor, the causes that produce this negative ministry may vary greatly. This chapter will consider the five illustrative causes presented in canon 1741. These two canons should be interpreted in relation with one another. Canon 1740 contains the implicit causes for the removal of a pastor: any cause which renders the pastor's ministry harmful or ineffective. Canon 1741 contains several explicit causes for a pastor's removal: a list of five causes that can result in the pastor's detrimental ministry. These five causes are examples which apply the standard for removal laid out in the previous canon. ${ }^{1}$ References will be made periodically to some of the topics mentioned in the first chapter. While it is not possible to mention every connection with the previous chapter, it suffices to recall that each of the five causes considered in this chapter should be thought of in light of the observations of the previous chapter.

\footnotetext{
${ }^{1}$ Coccopalmerio, De Causis, 275. Grocholewski, 213
} 


\section{Detriment or Disturbance to Ecclesiastical Communion (C. 1741, $1^{\circ}$ )}

The first cause for the removal of a pastor is "a manner of acting which brings grave detriment or disturbance to ecclesiastical communion." 2 This cause focuses on a manner of acting (modus agendi) of the pastor. A modus agendi is very broad and encompasses a range of actions. Because the pastor's actions are not limited to any specific sphere, these actions could be ministerial or non-ministerial in nature; that is, they could be connected to what the pastor does while performing his parochial duties, or what he does while he is away from the parish. ${ }^{3}$ Even if this modus agendi is non-ministerial in nature, the pastor cannot be removed unless his manner of acting somehow renders his ministry harmful or ineffective. The modus agendi could be connected to the pastor's own personal words and actions, or his act of approving of something harmful which is introduced by another person.

Although the modus agendi is in one sense very broad, it must also be specifically related to some concrete action on the part of the pastor that is demonstrable and manifest. ${ }^{4}$ The modus agendi must be an action and not a characteristic, quality, or appearance. For example, a pastor harms his parishioners if he publicly ridicules home schooling families, but not if his stern demeanor simply gives the appearance that he is critical of those who do not attend his parochial school. The modus agendi must be attributed to the pastor and not merely to some other person. For example, a pastor preaches error if he personally advocates the

\footnotetext{
${ }^{2}$ C. $1741,1^{\circ}$ : "modus agendi qui ecclesiasticae communioni grave detrimentum vel perturbationem afferat."

${ }^{3}$ Coccopalmerio, De Causis, 282.

${ }^{4}$ Ibid., 300.
} 
ordination of women, but he might not be responsible for his director of religious education who may believe that women have a right be ordained. The modus agendi must be demonstrable and not vague. For example, a pastor demonstrably violates the law if he invites all Protestants to receive the Eucharist, but not if he simply offers them words of welcome at Mass. The modus agendi must be externally manifest and not merely suspected or rumored. For example, a pastor harms his relationship with his bishop if he preaches against a diocesan tax, but not if it is rumored that he does not like the way his diocese raises money. These characteristics of the modus agendi flow from the observation in the previous chapter that a pastor can only be removed for a cause which is juridically proven.

The actions of the pastor must somehow affect ecclesiastical communion (communio ecclesiastica). As discussed with respect to canon 529 §2, a pastor may harm the horizontal communion that binds the parishioners together, the vertical communion that unites the parishioners under the authority of the diocesan bishop and the pope, or the triple bonds of faith, sacraments, and governance. The bond of communion can be broken by heresy (the obstinate denial or doubt of a truth that is to be believed by divine and Catholic faith), by apostasy (the total repudiation of the Christian faith), or by schism (the refusal of submission to the pope or a refusal of communion with the other members of the Church). ${ }^{5}$ A pastor who has personally committed one of these delicts may be subject to a penalty. However, the removal of a pastor depends not so much on his commission of a delict but rather on his detrimental ministry. Therefore, this cause for removal applies only when the

\footnotetext{
${ }^{5}$ C. 751 .
} 
pastor's actions have affected the faithful by leading them to doubt or reject some element of their communion with the Church. A pastor may be removed for harm to communio ecclesiastica under this cause only when it can be proven that his actions have affected at least some portion of the faithful.

The actions of the pastor must bring grave detriment or disturbance (detrimentum vel perturbatio) to this communion. Detrimentum implies an act that injures or wounds communion. Perturbatio implies an act that weakens communion or places it in peril. Detriment and disturbance are not equivalent to breaking or defecting from communion. If a pastor were to break communion or formally defect from the Catholic faith, he loses office by the law itself. ${ }^{6}$ The detriment or disturbance to ecclesiastical communion must be grave but need not be so severe that communion is actually broken. It must be shown that the pastor has seriously injured or weakened the bond of communion among the people of God. It is sufficient to demonstrate that the pastor's actions have fostered dissension, sustained a lack of peace, scandalized the faithful, or promoted a lack of reverence toward legitimate authority. $^{7}$

It has been previously observed that any cause for removal must be grave. In this light, the pastor's actions must jeopardize some essential element of ecclesiastical communion. For example, a pastor who consecrates invalid matter at Mass threatens a fundamental sacramental element of ecclesiastical communion: the Eucharist. ${ }^{8}$ On the other hand, a pastor who wears an illegitimate blue vestment on a Marian feast

\footnotetext{
${ }^{6}$ C. $194 \S 1,2^{\circ}$.

${ }^{7}$ Coccopalmerio, De Causis, 283.

${ }^{8}$ C. 924.
} 
commits a less significant liturgical offense. However, the adjective grave (gravis) in this canon specifically modifies detrimentum. Grammatically, the adjective gravis should be taken distributively to mean "grave detriment or grave disturbance." In other words, not only must the threatened object be essential to maintaining ecclesiastical communion, but the manner in which communion is threatened must also be grave. For example, a pastor gravely threatens the bond of faith if he publicly encourages the use of contraception, but the threat to communion is less severe if he advocates contraception when privately counseling a few married couples. The judgment of the gravity of the cause for removal is left to the diocesan bishop. Nevertheless, the cause must be sufficiently grave that removal is necessary in order to safeguard the good of souls.

\section{Ineptitude or Infirmity (C. 1741, $\left.2^{\circ}\right)$}

The second cause for the removal of a pastor is "ineptitude or a permanent infirmity of mind or body which renders the pastor unable to fulfill his functions usefully." A pastor can be removed for ineptitude (imperitia) or infirmity (infirmitas). Imperitia is the opposite of knowledge, skill, or expertise (peritia). An inept pastor is unable to act or acts poorly because of ignorance, a lack of discretion of judgment, or a fault of character. On the other hand, infirmitas is an illness or condition that affects a pastor's health. An infirm pastor can suffer from either a mental or a bodily illness. ${ }^{10}$

\footnotetext{
${ }^{9}$ C. $1741,2^{\text {o: }}$ "imperitia aut permanens mentis vel corporis infirmitas, quae parochum suis muneribus utiliter obeundis imparem reddunt."

${ }^{10}$ Coccopalmerio, De Causis, 285.
} 
The canon explicitly requires that infirmitas be permanent (permanens) to be sufficient for the removal of a pastor. Therefore, this cause for removal would not apply to a pastor who is gravely ill but expected to make a recovery. The pastor may be removed if he will not recover his health, or at least if the probability of recovering in the foreseeable future is remote. While a temporary illness may cause the ministry of the pastor to suffer, this problem can be overcome through the appointment of a parochial vicar or a parochial administrator who can meet the pastoral needs of the parish for a time. ${ }^{11}$ It was observed in the first chapter that a cause for removal must be lasting. The illness is lasting if it will affect the pastor perpetually or for an indefinite period of time. While a pastor possesses stability in office for the sake of the people whom he serves, he may be removed when the long duration of his illness causes more harm than good to the faithful. In the case of a protracted illness, the ministerial needs of the parish outweigh the right of the pastor to stability in office, and the pastor may be removed.

The canon does not indicate that imperitia must be permanens. However, ineptitude is an enduring (not temporary) quality that inhibits the pastor from acting in the way he should. Hence, in this context, imperitia is implicitly permanens. This enduring quality of imperitia is consistent with the observation in the previous chapter that any cause for removal must be lasting. The pastor must have a certain pastoral art or tact in order to fulfill his ministry. ${ }^{12}$ The inept pastor does not possess this pastoral art because of a lack of knowledge, expertise, or skill. Although a pastor

\footnotetext{
${ }^{11}$ Ibid., 281.

${ }^{12}$ Marzoa, 2115.
} 
may or may not be aware of his ineptitude, this cause for removal depends on the pastor's inability to minister to his parish and not on the pastor's recognition of his lack of ability.

Both imperitia and infirmitas must render the pastor unable to usefully fulfill his functions. The Latin text says that the obstacle renders the pastor unequal (impar) to the duty (munus) which must be usefully (utiliter) fulfilled. A pastor who cannot fulfill his munus is unable to provide adequate ministry, and therefore can be removed in virtue of canon 1740. Yet, only an ineptitude or illness that impacts the ministry of the pastor can be used as a cause for removal. For example, a pastor who has a basic knowledge of Spanish and is able to prepare a Spanish homily with the help of a translator may usefully minister to a parish that has a number of Spanish speaking members. Similarly, a pastor who suffers from a chronic but treatable illness may usefully fulfill his ministerial obligations, such as a pastor who manages his diabetes with insulin. This cause for removal requires proof of the pastor's ineptitude or illness, and proof of its effect on the pastor's ministry. The pastor's deficiency must gravely affect either some essential part of his ministry or his ministry as a whole, and must result in some harm to the people in his care.

A pastor who does not perform his duties usefully (utiliter) has failed to provide his people with the ministry that they deserve. Utiliter can imply either that the pastor does not act in regards to an obligation of his office, or that he acts poorly in a way that is inadequate to the needs of his parish. No pastor fulfills all his pastoral duties perfectly, but a pastor who ministers usefully at least meets his essential obligations to his people. An obstacle that prevents the pastor from 
fulfilling his essential duties usefully would be sufficiently grave to justify the pastor's removal. The judgment of what makes a pastor's ministry useful must be considered in light of the needs of the persons in a particular parish. ${ }^{13}$ For example, a pastor who is only able to give simple or down-to-earth homilies may usefully minister to a largely rural and less educated parish, but may not minister usefully to a more educated parish near a university that expects more scholarly preaching. Similarly, a pastor who is prevented from driving after sundown by a physical condition may usefully minister to a small inner-city parish with limited parish boundaries, but may not minister usefully to a rural parish that requires the pastor to drive great distances at night to answer a sick call.

The code gives examples of physical infirmities that can impact the ministry of a pastor. A priest may have difficulty in offering Mass if he cannot stand, is blind, or suffers from another infirmity. While the code allows a priest in this situation to continue offering Mass as best he can, he may not be able to celebrate Mass in public, as the people may be scandalized. ${ }^{14}$ A pastor who has such difficulties in offering Mass would be hindered in providing an essential aspect of his ministry and should resign his parish.

The law provides a further example of a psychological infirmity that could affect a priest. A severe psychic illness may cause a priest to be impeded altogether

\footnotetext{
${ }^{13}$ Coccopalmerio, De Causis, 284-285. Parizek, 1038. When a priest is appointed pastor of a parish, he must be judged suitable to be pastor of that specific parish, and not merely suitable to be a pastor in general. See Coccopalmerio, De Paroecia, 120.

${ }^{14}$ C. 930 . The local ordinary may judge whether a priest in these circumstances can offer Mass publicly.
} 
from the exercise of orders. ${ }^{15}$ Yet, even a less severe mental illness may affect the pastor's ability to provide pastoral ministry. A pastor who suffers from some mental illness should resign his office if his condition prevents him from fulfilling his essential pastoral responsibilities. In some cases, a pastor may not recognize the significance of his mental disability, and the diocesan bishop appropriately intervenes to remove the pastor.

A priest may be less and less able to fulfill his pastoral responsibilities simply due to his advanced years. The code requests that a pastor submit his resignation from office at age seventy-five. ${ }^{16}$ His resignation is requested but not required, since the pastor may still have the vigor necessary to continue his ministry beyond the age of seventy-five. When a pastor does submit his resignation, his bishop decides whether to accept the resignation or defer it for a time. Any bishop is similarly requested to submit his resignation at age seventy-five. However, a bishop is also requested to submit his resignation when he is less able to fulfill his office because of ill health or another grave cause. ${ }^{17}$ While a pastor is not explicitly invited to resign his office in the case of sickness, his bishop can name a parochial administrator when a pastor is prevented from exercising his office by reason of captivity, exile, banishment, incapacity, or ill health. ${ }^{18}$ If a pastor anticipates that he will not improve, it is appropriate that he (like a bishop) submit his resignation. If a pastor resigns his

\footnotetext{
${ }^{15}$ Cc. $1044 \S 2,2^{\mathrm{o}}$ and $1041,1^{\mathrm{o}}$.

${ }^{16}$ C. $538 \S 3$.

${ }^{17}$ C. 401 .

${ }^{18}$ C. 539 . Sweeny, 213. Sweeny notes that Christus Dominus 31 invites a pastor to spontaneously offer his resignation when he is unable to fulfill his office due to old age or another serious reason. See Vatican Council II, Decree Christus Dominus 31, 28 October 1965, AAS 58 (1966) 689.
} 
office for reasons of health, his bishop should provide support commensurate with the norms governing a retired pastor, even if the priest in question is not yet seventy-five years old. ${ }^{19}$ It was previously observed that canon 1740 permits the removal of a pastor even through no personal fault of his own. A pastor's declining health is a good example of a cause for removal in which the pastor is not personally at fault for his deficient ministry.

In addition to these examples of infirmity in the code, there are other circumstances that could lead to the removal of a pastor, provided the cause for removal is grave, lasting, and proven. A pastor might suffer from senility which affects his ability to effectively preach or to keep appointments. A pastor might recover from an illness but be left in a permanently weakened state, such that he lacks the strength to fulfill even his minimal responsibilities. A pastor might lack the skill to govern his parish if he repeatedly shows extremely poor judgment in handling daily affairs, or allows the property of the parish to fall into a serious state of disrepair.

\section{Loss of a Good Reputation or Aversion to the Pastor (C. 1741, $3^{\circ}$ )}

The third cause for the removal of a pastor is "loss of a good reputation among upright and responsible parishioners or an aversion to the pastor which it appears will not cease in a brief time." ${ }^{20}$ A pastor may be removed for the loss of his good reputation (bonae existimationis amissio), or for an aversion to him (aversio in

\footnotetext{
${ }^{19}$ See c. $538 \S 3$.

${ }^{20}$ C. 1741, 30: "bonae existimationis amissio penes probos et graves paroecianos vel aversio in parochum, quae praevideantur non brevi cessaturae."
} 
parochum). Both the amissio and the aversio entail a negative perception of the pastor on the part of his parishioners, or at least a substantial proportion of them. To be sufficient for removal, this negative perception must impact the pastor's ability to conduct his ministry, either because the faithful refuse to accept his ministry, or because they have serious difficulty in doing so. ${ }^{21}$

A bonae existimationis amissio occurs because some negative quality causes the people to critically judge (existimare) him. The negative judgment must be based on a visible quality, and therefore the loss of a good reputation is an objective reality which must also be objectively proven. A pastor who has lost his good reputation is considered suspect and untrustworthy, which may result in the rejection of his ministry by the faithful. In the words of St. Gregory the Great, "When the conduct of one is scorned, so too is his preaching., 22

In order to prove that a pastor's reputation has objectively suffered, his reputation must be weighed from the perspective of upright and responsible parishioners (penes probos et graves paroecianos). Parishioners are probi if they are good, honest, and reject lies. These persons will examine (probare) a thing before drawing a conclusion and will form a judgment based on the truth. Parishioners are graves if they are serious and do not judge lightly. These persons will weigh a situation before forming a negative judgment. Parishioners who are probi et graves will recognize that an evil must be significant and established before it can

\footnotetext{
${ }^{21}$ Coccopalmerio, De Causis, 288.

${ }^{22}$ Gregory the Great, Homilies, 22, ML 76, 1119, quoted in Marzoa, 2116.
} 
legitimately affect a pastor's reputation. These parishioners will not leap to a negative judgment on hearsay or rumor. ${ }^{23}$

Alternatively, aversio in parochum occurs when parishioners have a negative reaction to their pastor, which causes them to reject his ministry. ${ }^{24}$ Unlike the loss of a good reputation, aversio is not principally based on a negative quality of the pastor in se, but on the negative reaction of the parishioners to the pastor. This negative reaction can arise for objective or subjective reasons. Aversio is objective if the basis for the aversion of the parishioners is founded in the actions of the pastor. Aversio is subjective if there is no evil in the pastor, but a negative reaction has arisen due to other circumstances. $^{25}$ For example, parishioners may have an aversion to their pastor because they believe he is prone to anger. Their aversion is objective if it arises from witnessing the pastor firmly disciplining an erring parishioner. It is subjective, if the pastor simply has a severe appearance, or it is merely rumored that he has a temper. A pastor can be removed even for a merely subjective aversion, since the cause for removal does not require demonstrating any personal fault on the part of the pastor. ${ }^{26}$

\footnotetext{
${ }^{23}$ Coccopalmerio, De Causis, 289.

${ }^{24}$ M. de Sancristóval y Murúa, "El 'Odium Plebis' como Causa de Remoción del Parroco," Ius Canonicum 1 (1961) 402. For removal, the aversio must not be directed at the office of the pastor, but at the person of the pastor. Aversio may be directed at the office of the pastor if the pastor is disliked because of something he was bound to do by office. For example, some parishioners may dislike their pastor because he refuses their request to frequently offer general absolution. Removal will not solve this problem, because the next pastor will presumably be rejected for the same reason. Removal can proceed if the aversio is directed at the person of the pastor because of who he is or the abrasive way in which he carries out his duties.

${ }^{25}$ Coccopalmerio, De Causis, 289.

${ }^{26}$ C. 1740 . A merely subjective aversio on the part of the parishioners can result in gravely harmful or ineffective ministry, and suffices for removal. Yet, if the pastor is a virtuous man and the aversio of the faithful is merely subjective, it may not be prudent to dishonor the pastor by removing him, especially if the ill will among the parishioners is rooted in some bigotry. If the diocesan bishop
} 
The stability of a pastor is meant to foster a spiritual relationship between a pastor and his people through his ministry. When parishioners develop an aversio to their pastor, even the good efforts of the pastor in his ministry will be rejected. Aversio results in harm to souls because the parishioners are unable to draw benefit from the pastor's ministry. It is because of the concern for the good of souls that a pastor can be removed because of an aversio on the part of the faithful.

The loss of reputation or the aversion to the pastor must be foreseen not to cease in a brief time (quae praevideantur non brevi cessaturae), and must therefore be lasting. A pastor should not be removed if his parishioners are upset only for a time because of a decision he has made. For example, a parish might be upset only for a time if a pastor was compelled to close his parish school. The negative sentiment in the parish does not appear to cease quickly if the level of discontent remains consistent or increases over time. Only a negative sentiment that is lasting can constitute a grave cause sufficient for the removal of the pastor.

Some other factors should also be considered. First, the amissio or aversio should be held by a large number of the parishioners, although it does not need to be universal. $^{27}$ In every parish, there will always be some parishioners who like their pastor and others who dislike their pastor. The opinion of only a few persons is insufficient as a cause for removal, and the mere existence of a negative perception of

determines that the pastor cannot remain in the parish, he might demonstrate his trust and confidence in the pastor by transferring the priest to another parish as pastor or to another significant office within the diocese. See Coccopalmerio, De Causis, 293.

${ }^{27}$ Codex Iuris Canonici Pii X Pontificis Maximi iussu digestus Benedicti Papae XV auctoritate promulgatus (Rome: Typis Polyglottis Vaticanis, 1917) C. $2147 \S 2,2^{\circ}$ (hereafter CIC 1917). The 1917 code did not require the odium plebis to be universal for a pastor to be removed, but significant enough to impede the ministry of the pastor. 
a pastor by some parishioners does not mean that his removal must follow automatically. The diocesan bishop must judge whether the discontent seriously affects the pastor's ministry in his parish. The aversion or the loss of a good reputation does not generally arise out of one isolated event, but rather from a pattern of behavior over time. This pattern leads to the attribution of a poor reputation or the development of aversion by the faithful. It is possible that early intervention may lead a pastor to change his ways, thus healing the rift in the parish, and avoiding the need for removal. ${ }^{28}$

Second, when a pastor commits a delict, he may be punished by a penalty provided that prescription has not extinguished this possibility. However, even if no action may be brought against the pastor because of the passage of time, a past crime that becomes widely known in a parish may result in a loss of the pastor's reputation or an aversion to him. Although this circumstance was specifically mentioned in the 1917 code, it was not explicitly repeated in the 1983 code. ${ }^{29}$ However, the discovery of a past crime can still form a sufficient basis for the removal of a pastor under this cause if the loss of the pastor's reputation renders the pastor's ministry gravely harmful or ineffective.

Third, it appears unbefitting to use a manifestly unjust perception of the pastor as the reason for his removal. ${ }^{30}$ Some parishioners may form a negative opinion of

\footnotetext{
${ }^{28}$ Coccopalmerio, De Causis, 292.

${ }^{29}$ CIC 1917 , c. $2147 \S 2,3^{\circ}$.

${ }^{30}$ Parizek, 1037. The 1917 code permitted a pastor to be removed if his reputation suffered because of the crime of a family member or a person with whom the pastor lives $\left(C I C 1917\right.$, c. $\left.2147 \S 2,3^{\circ}\right)$. This provision was not retained in the 1983 code, perhaps because it appeared unjust for a pastor to suffer because of the evil deeds of another.
} 
their pastor because his preaching on faith and morals challenges their consciences. Such a pastor should not suffer removal on account of his fidelity to his mission. Alternatively, a pastor may be falsely accused of wrongdoing and yet be able to prove his innocence. Even if some parishioners remain suspicious of their pastor, it is fitting for the diocesan bishop to help rehabilitate this pastor's reputation rather than remove him from office. ${ }^{31}$

There are many circumstances that might lead to the removal of the pastor under this cause. With respect to the loss of a good reputation, any crime or seriously immoral behavior could imperil a pastor's ministry. A pastor who is addicted to alcohol or to gambling might lose his good name. Obviously a serious sexual addiction, especially related to child abuse, would cause a pastor's reputation to suffer. With respect to aversion of the faithful, a parish might come to disdain a pastor who frequently had outbursts of irrational anger. A foreign pastor might be disliked by his parish if his English was so poor that no one could understand him. A parish might become averse to a pastor who showed grave imprudence in managing the parish assets, perhaps by spending exorbitant amounts of money on the pastor's private rectory while neglecting to provide for other needed improvements in the church. ${ }^{32}$ An aversion to the pastor might also arise from a particular circumstance in a parish. A pastor with a traditional liturgical style might be despised by a parish

\footnotetext{
${ }^{31}$ de Sancristóval, 402. In matters of sexual abuse, when an accusation against a cleric is shown to be unfounded, a diocesan bishop should attempt to restore the cleric's good name. See United States Conference of Catholic Bishops, Decree Essential Norms for Diocesan/Eparchial Policies Dealing with Allegations of Sexual Abuse of Minors by Priests or Deacons, Art. 13, 5 May 2006 (Washington, DC: USCCB, 2006).

${ }^{32}$ This example could fall under the fifth reason for removal due to the poor administration of temporal affairs if grave harm came to a parish because of the pastor's actions.
} 
accustomed to a more progressive style, especially if he attempted too quickly to make radical changes in the life of the parish, perhaps by firing a beloved musician in order to change the style of music.

\section{Neglect or Violation of Parochial Duties (C. 1741, $4^{\circ}$ )}

The fourth cause for the removal of a pastor is "grave neglect or violation of parochial duties which persists after a warning." ${ }^{33}$ A pastor may be removed for a neglect (neglectus) or a violation (violatio) of his duties. A violatio is an action contrary to an obligation while neglectus is a failure to meet an obligation. The combination of neglectus vel violatio is comprehensive since it encompasses actions in both the positive and negative sense. This pairing of words is similar to the description of harmful or ineffective ministry, which encompasses a pastor's deficient ministry in both the active and the passive sense.

The offence must be with respect to the pastor's essential parochial duties (officiorum paroecialium) which were discussed in the first chapter. ${ }^{34}$ The pastor may be removed for a failure to provide adequate ministry of the word through his homilies and catechetical instruction, or a failure to offer sufficient access to the sacraments for his parishioners. The pastor may be removed if he fails to properly govern his parish and care for his parishioners. A pastor is obligated to promote communion, although a violation or neglect in this area would most likely be treated under the first cause for removal. A pastor is bound to properly care for the assets of

\footnotetext{
${ }^{33}$ C. $1741,4^{\circ}$ : "gravis neglectus vel violatio officiorum paroecialium quae post monitionem persistat."

${ }^{34}$ Canon 2182 of the 1917 code provided for the removal of a pastor who was negligent in specific pastoral duties. Each of these duties is reflected in canons 528-530 of the 1983 code except for one: A pastor could be removed if he failed to protect the cleanliness of the parish church or if he permitted business transactions in the church (CIC 1917, cc. 1178 and 2182).
} 
a parish, although harmful or ineffective financial management of these assets would be covered under the fifth cause for removal.

It was observed in the first chapter that a grave cause is required for the removal of a pastor. A pastor's offence with respect to his parochial duties is grave if the pastor violates or neglects a duty that is essential to his office. A pastor's failure with respect to a non-essential duty would not constitute a grave cause. However, the adjective "grave" (gravis) modifies neglectus, which requires not only that duty which is neglected must be essential to the pastor's ministry, but that the failure of pastor to do his duty must also be grave. For example, a pastor who occasionally neglects to visit the sick should not be removed from office, while a pastor who notoriously fails to visit his parishioners in the local hospital has gravely neglected his duty. Although the canon only indicates that the neglectus must be gravis, this adjective should be read distributively so that a violatio must also be grave to justify removal. For example, a pastor who takes a few more days of vacation time than permitted should not be subject to removal. However, a pastor whose frequent trips cause him to be absent from his parish for several months out of a year has gravely violated his obligation of residence. ${ }^{35}$

A pastor may be removed under this cause only after a warning (post monitionem). This monitio places the pastor on notice by means of a paternal correction and gives him an opportunity to reform his behavior. The pastor must have sufficient time to change his behavior after the warning, before he can be removed. This monitio can be given by the diocesan bishop, or by another local

${ }^{35}$ C. 533. 
ordinary such as the vicar general, although only the diocesan bishop can undertake the removal of the pastor. The monitio can be given verbally or in writing. Witnesses should be present if the monitio is given verbally so it can be juridically established if a procedure for removal is subsequently initiated. ${ }^{36}$ After the warning is given, the removal can only be effected if the offensive behavior persists (quae . . persistat). ${ }^{37}$ The behavior persists if the manner of acting does not change or becomes worse after a suitable period of time. Like the monitio, the persistence of the pastor's negative behavior must also be certainly established. The monitio and the subsequent persistence of the offensive behavior help to prove that the cause for removal is lasting.

\section{Poor Administration of Temporal Affairs (C. 1741, $5^{\circ}$ )}

The fifth cause for the removal of a pastor is "poor administration of temporal affairs with grave damage to the Church whenever another remedy to this harm cannot be found." ${ }^{38}$ A pastor may be removed for poor administration of temporal affairs (res temporales). The canon uses res temporales, and not simply ecclesiastical goods (bona ecclesiastica) or temporal goods (bona temporalia). There is no doubt that the assets of a parish, as a public juridic person, are bona ecclesiastica and are

\footnotetext{
${ }^{36}$ Coccopalmerio, De Causis, 295. The 1917 code explicitly required the warning to be given in writing or orally before witnesses (CIC 1917, c. 2143).

${ }^{37}$ Coccopalmerio, De Causis, 296. Grammatically speaking, because quae is feminine and persistat is singular, the antecedent of this relative clause is the feminine noun, violatio. The other noun, neglectus, is masculine. However, it would be incorrect to conclude that only a violation must persist, but that a pastor can be removed for pastoral neglect whether it persists or not. In Latin, a relative pronoun that agrees with its closest antecedent may still be taken distributively. Coccopalmerio argues convincingly that the relative clause should be rewritten for clarity in the plural, qui . . persistant, in order to eliminate any doubt and to specify that neglect also must persist to justify removal.

${ }^{38}$ C. $1741,5^{\circ}$ : "mala rerum temporalium administratio cum gravi Ecclesiae damno, quoties huic malo aliud remedium afferri nequeat."
} 
governed by the canons of book five of the code. ${ }^{39}$ However, res temporales is a broader concept and encompasses the manner in which temporal goods are used. The temporal affairs of a parish should be rightly ordered so that the assets of the parish are protected, but also so that the acquisition, retention, administration, and alienation of those goods are done with integrity and according to canon law and civil law. ${ }^{40}$ For example, a pastor who defrauds people to raise money may increase the temporal goods of his parish, but he is a poor administrator of its temporal affairs because he acts in a dishonest way.

A pastor may be removed for poor administration (mala administratio). Mala administratio includes any violation of the law, especially the canons of book five of the code, but also a violation of particular law or the statutes of the parish. Mala administratio includes both positive acts that harm the financial standing of the parish, and negative acts of the omission of some required act of diligence for the protection of the goods of the parish. A positive act of harm to parochial goods can render the pastor's ministry harmful, just as a negative act of omission can render the pastor's ministry ineffective. Mala administratio may include other acts not proscribed by law. For example, a pastor demonstrates poor administration if he takes an action that is licit, but imprudent and results in some financial harm. ${ }^{41} \mathrm{~A}$

\footnotetext{
${ }^{39}$ C. $1257 \S 1$.

${ }^{40}$ Canon $1284 \S 2,3^{\circ}$ mentions the importance of observing civil and canon law. The purpose of res temporales is mentioned in other canons: Canon $225 \$ 2$ speaks of the obligation of the faithful to imbue and perfect the order of temporal affairs (res temporales) with the spirit of the gospel. Canon $768 \S 2$ makes reference to the obligation of those who preach to make known the doctrine set forth by the magisterium concerning the right ordering of temporal affairs (res temporales) according to the plan established by God.

${ }^{41}$ Coccopalmerio, De Causis, 297.
} 
pastor may be a poor administrator if he causes the parish to go into debt by regularly spending more money than the parish receives.

The fact that a parish has decreasing revenues or rising debts does not automatically prove that the pastor has been a poor administrator. It may happen that a parish cannot avoid losing money if its membership is declining, the cost of maintaining old parish buildings is rising, or the support of a parochial school draws upon the parish reserves. While consistently declining revenues is a cause for concern and may require serious action, this fact alone does not automatically mean that the pastor is guilty of mala administratio.

Because of the many responsibilities of the pastor, the day-to-day administration of financial matters is often handed over to another knowledgeable person, such as a parish bookkeeper. Even if the bookkeeper handles the financial recordkeeping, the pastor is still responsible for overseeing the administration of the temporal affairs of the parish. A pastor is responsible for the mala administratio of the parish's assets if he hires an unqualified bookkeeper or fails to discipline a bookkeeper after discovering some act of mismanagement. ${ }^{42}$

As with any cause for removal, the mala administratio must be grave to justify removal. For example, a pastor who invalidly alienates the stable patrimony of a parish commits a grave violation of the law, while a pastor who fails to prepare the recommended budget does not commit a grave offense. ${ }^{43}$ However, this cause for removal requires that the mala administratio must also result in grave damage to the

\footnotetext{
${ }^{42}$ Ibid., 298.

${ }^{43}$ Cc. $1284 \S 3$ and 1291.
} 
Church (cum gravi Ecclesiae damno). The damnum must be grave such that removal is required for the sake of the parish and consequently for the good of souls. The damnum must be proven by means of objective and demonstrable evidence. It is necessary to prove not only that damage has been done, but that there is also a cause and effect relationship between the mala administratio of the pastor and the damnum suffered by the Church. For example, a pastor might invalidly alienate some parish property, but the transaction might be very beneficial to the parish. In this case, the pastor is guilty of poor administration and may be subject to a penalty, but removal is not warranted because the parish suffered no harm. The diocesan bishop judges whether the damage is proven and sufficiently gravis to warrant removal.

The grave damage must be done to the Church (Ecclesia). With respect to temporal goods, the term Ecclesia in book five of the code refers to any public juridic person. ${ }^{44}$ Therefore, a pastor may be removed for poor administration of temporal affairs which has caused grave harm to any public juridic person, including his parish or his diocese. In most circumstances of financial negligence, the grave damage will directly affect the parish. However, a pastor may be removed if grave damage was done to the diocese or another public juridic person in the Church, even if the parish suffered no harm. ${ }^{45}$ For example, the diocese might suffer if a pastor's willful negligence results in a sizeable insurance claim from a self-insured diocesan fund that depletes diocesan assets and leads to dramatically higher insurance premiums for every other parish in the diocese.

\footnotetext{
${ }^{44}$ C. 1258.

${ }^{45}$ Coccopalmerio, De Causis, 298.
} 
If the entity that suffered the grave harm was not a public juridic person, the diocesan bishop should demonstrate how the pastor's poor financial administration has harmed the Church before he removes the pastor. It may be possible to argue that financial harm to a private juridic person constitutes harm to the Church, especially if the private juridic person performs a function essential to the Church's mission. For example, the financial harm might affect a Catholic hospital or a Catholic association that serves the poor which has been established as a private juridic person. If the financial harm was suffered by one or more private individuals, removal is justified under this cause only if the Church has also suffered actual harm. For example, the Church would suffer if the aggrieved party or parties brought a lawsuit against the parish or the diocese because of the pastor's actions. However, if a pastor's poor administration of another person's finances does not result in grave harm to the Church, the pastor cannot be removed under this fifth cause. Even so, the pastor's unscrupulous financial management might result in the loss of his reputation, which could lead to his removal under another cause.

Removal may be effected only when no other remedy to this harm can be found (quoties huic malo aliud remedium afferri nequeat). This provision distinguishes this fifth cause for removal from the neglect or violation of pastoral duties in the fourth cause. When the diocesan bishop notices that a priest fails in a pastoral duty, he must give him a warning before proceeding to removal. In the case of poor financial administration, the diocesan bishop must not simply warn the pastor, 
but he must attempt to find another remedy before proceeding to removal. ${ }^{46}$ Removal is to be a refuge of last resort.

One possible remedium could come from a professional audit or the assistance of an accountant. A pastor who is able to balance his books with the help of a qualified lay person may avoid removal. Another possible remedium is the appointment of an administrator or a parochial vicar to oversee the finances of the parish. A pastor who lacks financial skill may remain in office if his financial duties are cared for by another priest. The appointment of an administrator for parish finances is especially appropriate if the financially inept pastor is truly gifted in the other aspects of his ministry. ${ }^{47}$ However, the pastor may object to this appointment and might refuse to relinquish his authority to administer the temporal goods of his parish which he has by office. ${ }^{48}$ If the diocesan bishop attempts to appoint someone to help manage the finances, but the pastor refuses to cooperate, the bishop might conclude that no other remedy is possible and that the pastor must be removed.

It may be that no remedium whatsoever is possible because of the nature of the grave harm. If the harm has occurred because of a one-time fault that cannot be reversed, there may be no other solution. For example, a pastor may pay a large amount to a disreputable contractor for a building project. If the pastor's negligence to heed legitimate warnings about the contractor or his failure to insure his project results in the irrevocable loss of millions of dollars, there may be no possible remedy

\footnotetext{
${ }^{46}$ Marzoa, 2118.

${ }^{47}$ Coccopalmerio, De Causis, 299. Ineptitude in financial matters might also be treated under the second cause for removal if the focus is on the ineptitude of the pastor and not the financial harm to the parish.

${ }^{48}$ Cc. 532 and $1279 \S 1$.
} 
to this poor administration. If there is no alternative solution, the diocesan bishop should demonstrate the lack of a viable remedy before proceeding with the removal.

\section{Other Possible Causes}

Because the list of causes in canon 1741 is illustrative, there are theoretically other possible causes that might lead to the removal of a pastor. Many possible causes for removal were listed in the decree Maxima Cura, most of which are incorporated into the current code at least in a substantially equivalent form. One possible cause for removal not found in the current code is the pastor's disobedience of a precept of the ordinary in a grave matter. ${ }^{49}$ Under the 1983 code, disobedience of a precept can result in the imposition of a just penalty. ${ }^{50}$ However, disobedience should not be used for the removal of the pastor unless it can be proven that the act rendered the pastor's ministry gravely harmful or ineffective. Florentius Romita proposed other possible causes for the removal of a pastor in light of Vatican II: A pastor might be removed for failing to preserve parish unity, for resistance to the innovations of the Council, and for an inability to collaborate effectively within his parish, his vicariate, or his presbyterate. ${ }^{51}$ These reasons, which were proposed before the 1983 code, are encompassed in the general scope of the first cause: a disturbance of ecclesiastical communion.

\footnotetext{
${ }^{49}$ Maxima Cura, can. 1, $9^{\circ}$. A pastor might be removed if he disobeyed a precept that ordered him to avoid keeping inappropriate company with a person or a family, to care for the upkeep of his parish church, or to pay a parish tax.

${ }^{50}$ C. $1371,2^{\circ}$. It may be possible to remove a pastor who disobeys a precept of his ordinary if his disobedience results in a disturbance of ecclesiastical communion by leading the faithful to question or reject the bond of hierarchical governance.

${ }^{51}$ Romita, 440-441.
} 
The structure of the five causes in canon 1741 demonstrates that they address the possible reasons for the removal of a pastor in a systematic and comprehensive way. The first cause addresses the importance of the right relationship of the pastor with the church (ecclesiastical communion). The second and third causes address an inability to provide ministry. In the second cause, the inability is on the part of the pastor (infirmity or ineptitude), while in the third cause the inability is on account of the parishioners who cannot accept the pastor's ministry (loss of reputation or aversion). The fourth and fifth causes address a deficiency in the pastor's ministry. In the fourth cause, the pastor's deficiency is in relation to his pastoral duties, while in the fifth cause, the pastor's deficiency is in governing the temporal affairs of his parish.

While there may be other possible causes to remove a pastor, it is likely that any cause will fall within the general scope of one of the five causes already presented. Nevertheless, because these causes are illustrative, it is entirely legitimate to pursue the removal of a pastor for a reason not found in canon 1741 provided that it can be demonstrated that the cause is grave, lasting, and proven, and that the cause rendered the pastor's ministry harmful or ineffective. 



\section{Chapter III: The Collection and Evaluation of Proofs}

The first two chapters considered the standards and causes for the removal of a pastor. This chapter considers the practical question of the manner of investigating the pastor's ministry. A pastor cannot be legitimately removed from office unless there is a cause for removal which is grave, lasting, and proven. ${ }^{1}$ The removal of a pastor requires an investigation of the pastor's ministry which seeks to establish, by the collection of proofs, whether there is a cause sufficient for removal. This chapter will consider both the manner of instructing a cause for removal and the different types of proof that might be gathered in the instruction.

\section{Part A: The Instruction of a Cause for Removal (C. 1742 §1)}

Canon 1742 begins with a brief conditional clause, "If the instruction which was carried out has established the existence of one of the causes mentioned in can. 1740." 2 The canon begins with the mention of an instruction (instructio) by which the cause is proven. Although the canon does not describe this instructio in any

\footnotetext{
${ }^{1}$ Daneels, 296. This passage was previously cited in the first chapter, footnote 11 .

${ }^{2}$ C. 1742 §1: "Si ex instructione peracta constiterit adesse causam de qua in can. 1740." This canon goes on to describe the procedural steps in the removal of a pastor after the instruction. The consideration of these procedural steps is beyond the scope of this thesis.
} 
further detail, it should be understood in light of other parallel references in the code to an instruction. ${ }^{3}$

There is a verbal similarity between canon $1742 \S 1$ and canon $1428 \S 1$. In the procedure for the removal of a pastor, canon $1742 \S 1$ describes the steps after "the instruction has been carried out (instructione peracta)." In a trial, canon $1428 \S 1$ describes the role of an auditor who has been designated by a judge to "to instruct the case (ad causae instructionem peragendam)." Both of these procedures require an instructio which must be carried out (peragere) to establish the facts of the case. ${ }^{4}$ In a trial, the presiding judge (praeses) may instruct the case personally or designate an auditor who is known for his or her good character, prudence, and doctrine. The auditor collects the proofs according to the mandate of the judge, and hands them over to the judge..$^{5}$ In a procedure of removal, the diocesan bishop takes the place of the praeses. ${ }^{6}$ While the diocesan bishop can theoretically instruct the case personally, it is more likely that he will designate another person of good repute to carry out the instruction. The delegate who instructs the case should be a priest with some knowledge of canon law, although a degree in canon law is not required. ${ }^{7}$

\footnotetext{
${ }^{3}$ C. 17.

${ }^{4}$ Marzoa, 2119.

${ }^{5}$ C. $1428 \S \S 1-3$.

${ }^{6}$ Only the diocesan bishop is competent to decide the removal of a pastor from ministry (see c. 1740). The entire procedure for removal depends upon his judgment.

${ }^{7}$ There is no explicit requirement that a priest be chosen to instruct a case for the removal of a pastor. However, in any case in which a priest's reputation might be harmed, the notary must be a priest (c. 483). By extension, it is fitting for the instructor in a case of removal to be a priest. See Barbara Anne Cusack, "Title III: The Internal Ordering of Particular Churches (cc. 460-572)" in New Commentary on the Code of Canon Law (hereafter New Commentary), ed. John P. Beal et al. (New York/Mahwah, NJ: Paulist Press, 2000) 637. A delegate who has some knowledge of canon law will be able to insure that the procedure is carried out correctly.
} 
Several commentators suggest interpreting the instructio in canon $1742 \S 1$ in light of the preliminary investigation (investigatio) mentioned in canon $1717 .^{8} \mathrm{At}$ first, there appear to be some significant differences between these two procedures. The preliminary investigatio takes place before a penal process and examines the actions of the accused to determine whether the accused has committed a delict and is imputable for it. The instructio in a removal procedure is not part of a penal process and examines a pastor's ministry to determine whether the pastor should be removed from office. Even the terminology carries a different connotation since an investigatio connotes the searching (vestigare) for the truth, while an instructio connotes the building (struere) of a case.

However, there are many more similarities than differences between the instructio in canon $1742 \S 1$ and the investigatio in canon 1717 . There is an indirect connection because of the fact that the one who conducts a preliminary investigation has the powers of an auditor. ${ }^{9}$ The mention of an auditor links the investigation in canon 1717 with the role of the auditor in the instruction in canon $1428 \S 1$. The similarity in terminology between canon $1428 \S 1$ and canon $1742 \S 1$ has already been observed.

Even so, there are other direct similarities between the preliminary investigatio and the instructio in a procedure for removal. Both procedures are initiated only after there is evidence of something bad, whether a committed delict or

\footnotetext{
${ }^{8}$ Marzoa, 2119. Sweeny, 217. Grocholewski, 223. Thomas J. Paprocki, "The Method of Proceeding in Administrative Recourse and in the Removal or Transfer of Pastors (cc. 1732-1752)" in New Commentary, ed. John P. Beal et al., 1841. While each of these authors advocates interpreting the instructio in light of canon 1717, only Marzoa advocates also interpreting the instructio in light of canon $1428 \S 1$.

${ }^{9}$ C. $1717 \S 3$.
} 
poor pastoral ministry. Both procedures are undertaken to bring about a corrective action, whether through the imposition of a penalty or through removal from office. Both procedures are under the direction of the ordinary or his delegate who, like an auditor, is responsible for gathering evidence. While both procedures are relatively unstructured, the delegate in each procedure is confined to a narrow focus when gathering proofs and should not engage in a fishing expedition for unrelated evidence. Both procedures can take place prior to the notification of the concerned party. In the penal process, the accused is cited only after the preliminary investigation is completed; ${ }^{10}$ in a procedure for removal, the diocesan bishop must inform the pastor of the cause for removal and allow him to inspect the acts of the case only after the instruction of the cause is completed, and a determination has been made that the cause for removal has been proven. ${ }^{11}$ While the diocesan bishop may inform the pastor that he has initiated an instruction for the pastor's removal, he is not bound to do so. $^{12}$

The instructio in canon $1742 \S 1$ should also be considered in relation to canon 524 and the investigatio into the suitability of a newly appointed pastor. Before a diocesan bishop appoints a pastor, he is to make a judgment about the priest's suitability and is to "conduct appropriate investigations (aptasque investigationes

\footnotetext{
${ }^{10}$ The citation of the accused is not mentioned in the preliminary investigation (cc. 1717-1719) but is required in an extra-judicial administrative process (c. 1720) or a judicial process (see c. 1723). The citation of the accused is also required before imposing a cautionary restriction on the accused (c. 1722).

${ }^{11}$ Cc. $1742 \S 1$ and $1745,1^{\circ}$.

${ }^{12}$ Paprocki indicates that the diocesan bishop may inform the pastor about the investigation into his possible removal, although this is optional. See Paprocki, 1848.
} 
peragat)." ${ }^{13}$ The investigatio that is to be carried out (peragere) requires the bishop to hear the vicar forane and anticipates that the bishop may also hear other priests and lay persons before appointing a pastor. This canon has two implications for the instructio in a cause for removal. First, the persons who may be consulted before the appointment of a pastor (vicar forane, others priests, and lay persons) may also be appropriate witnesses in the removal of the pastor. Second, the results of the investigatio prior to the appointment of a pastor may provide a useful benchmark for evaluating the pastor's ministry in the procedure for removal. ${ }^{14}$ The tensions in a parish may be attributable to a pastor's detrimental ministry if the parish was relatively peaceful when the pastor was appointed (i.e., at the time of the investigatio described in canon 524), but has become contentious as his removal is considered (i.e., at the time of the instructio described in canon 1742 §1). Similarly, a pastor's ineptitude may be demonstrated if his suitability was proven at the time of his appointment, but the investigation for removal showed a loss of his mental or physical abilities.

\section{The Right of Defense and Right to a Good Name}

In a penal process, the accused always enjoys the right of defense. The right of the pastor to challenge the evidence against his ministry in the cause for his removal is similar, but not identical, to the right of defense in a trial. A removal procedure does not put the pastor personally on trial, but it does subject his pastoral ministry to scrutiny. When a pastor is removed for harmful or ineffective ministry,

\footnotetext{
${ }^{13}$ C. 524.

${ }^{14}$ The investigation before the appointment of the pastor should consider the state of the parish, the needs of the parish, and the desired qualities in the new pastor. See Coccopalmerio, De Paroecia, 120.
} 
his reputation will necessarily suffer. As the pastor has a right to protect his reputation from illegitimate harm, he necessarily has a corresponding right to defend his pastoral ministry. ${ }^{15}$

The rights of the pastor to defend his ministry are analogous to the rights of the accused in a penal process. In a penal case, the accused is permitted to know the charge against him, examine the proofs, challenge the evidence, and present his own contrary evidence. In a removal case, the pastor can claim the exercise of corresponding rights. The pastor has the right to be informed of the causes and reasons for removal at the time of the bishop's paternal persuasion. The pastor has the right to inspect the proofs and propose a defense, if he objects to the cause for removal. $^{16}$

Whether or not the diocesan bishop has chosen to inform the pastor that he has initiated an instructio into the pastor's possible removal, care must be taken to protect the pastor's right to defend his ministry. During the instruction of a contentious trial, the judge will make several decisions regarding proofs that are to be accepted and the proofs that are to be rejected. In each of these decisions, the parties have the right to raise incidental questions when they disagree with the judge's decision. These questions are to be decided by the judge as quickly as possible (expeditissime), and do not admit of appeal. ${ }^{17}$ Even though the judge's decision is final, a judge must weigh his decisions prudently and fairly in order to avoid irremediable nullity of sentence

\footnotetext{
${ }^{15}$ C. 220.

${ }^{16} \mathrm{Cc} .1742 \S 1$ and $1745,1^{\circ}$.

${ }^{17}$ Cc. $1527 \S 2,1589 \S 1$, and $1629,5^{\circ}$.
} 
should his decisions result in the denial of the right of defense. ${ }^{18}$ If the pastor is aware of the instructio into his possible removal from office, the delegate should carefully consider any actions or exceptions raised by the pastor in order to protect his right of defense. The delegate should decide any incidental questions raised by the pastor expeditissime and may decide to accept or reject a proof even over the pastor's objections. On the other hand, if the pastor is unaware of the instructio into his removal, the pastor will not be able to raise any incidental questions during the instructio. In this case, the diocesan bishop must carefully consider the objections which the pastor makes in his written report after he has seen the acts. ${ }^{19}$ The probative value of the proofs must be weighed, giving carefully consideration to the objections raised by the pastor, before reaching a decision about his removal. ${ }^{20}$ Whether the pastor is informed of the instructio or not, his right of defense must be respected.

In the instructio of a cause for removal, the delegate must take care not to endanger the pastor's good name. ${ }^{21}$ In practice, the care required to avoid harming the pastor's name will likely be one of the most difficult aspects of the instructio. The pastor's good name may already be impaired, especially if the pastor's removal is considered in light of the loss of his good reputation. The initiation of an instructio

\footnotetext{
${ }^{18}$ C. $1620,7^{\circ}$.

${ }^{19}$ C. $1745,1^{\circ}$.

${ }^{20}$ The diocesan bishop must weigh with two other pastors both the proofs which support the removal of the pastor and the pastor's written defense before making a decision for or against removal (c. 1745, $2^{\circ}$ and $3^{\circ}$ ).

${ }^{21}$ Cc. 220 and $1717 \S 2$. This position is held by Daneels and Sweeny. See Daneels, 297, and Sweeny, 217. All those involved in a procedure for removal were bound by secrecy under the 1917 code (CIC 1917 , c. 2144 §1).
} 
into the removal of the pastor will likely cause the pastor's reputation to suffer even more. Nevertheless, the delegate must proceed with caution to avoid making the situation worse because of the manner in which he conducts his instructio.

\section{Part B: The Collection of Proofs}

The delegate's responsibility in the instructio is the collection of proofs. The collection of proofs is governed by canons 1526-1586, although some of the provisions of these canons must be adapted in the context of an administrative procedure for the removal of a pastor. In a trial, an auditor who instructs a case functions in the place of the judge and acts according to his mandate when collecting proofs. The auditor decides what proofs are to be collected and may exercise the prerogatives attributed to the judge in the canons on proofs. ${ }^{22}$ Likewise in a procedure for removal, the delegate who investigates the ministry of the pastor functions in place of the diocesan bishop and acts according to the bishop's mandate. The delegate determines which proofs are to be collected. Because the delegate has the powers of an auditor, any powers attributed to the judge in canon 1526-1586 should also be applied to the delegate. ${ }^{23}$ If the diocesan bishop has not given specific directions to the delegate, the delegate may exercise his own prudential judgment when instructing a cause for removal.

\footnotetext{
${ }^{22}$ C. 1428 §3. Dignitas Conubii clarifies this point for matrimonial cases. The term "judge" is to be understood as also referring to the auditor. See Pontifical Council for Legislative Texts, Instruction Dignitas Conubii Art. 155 §2 (Vatican City: Libreria Editrice Vaticana, 2005) 126.

${ }^{23}$ The noun iudex appears 58 times in canons 1526-1586.
} 


\section{The Declarations of the Pastor (Cc. 1530-1538)}

The judge can always question the parties in a trial, and so the delegate has the right to question the pastor about his ministry. ${ }^{24}$ While the diocesan bishop is not obligated to inform the pastor that he has opened the instruction of the cause for his removal, the pastor will learn of his possible removal if the delegate decides to question him. In a penal process, the accused cannot be compelled to take an oath or confess a delict when giving testimony. In a procedure for removal, while the pastor is bound to answer the delegate's questions truthfully, the delegate should not compel the pastor to take an oath if the pastor is unwilling nor should he compel the pastor to answer a question that the pastor believes will incriminate him. ${ }^{25}$ If the pastor refuses to respond to a question, the diocesan bishop may determine what inference should be drawn from his silence. ${ }^{26}$

The delegate is not required to hear the pastor in the course of his instruction, as the pastor will have the opportunity to defend his pastoral ministry and present any exculpatory proofs after he reviews the acts of the case. However, the delegate should hear the pastor during his instruction when it will better protect the pastor's right of defense. In some cases, the delegate may wish to hear the pastor in order to better understand the cause for removal. For example, if many parishioners have developed an aversion to the pastor because of a decision he made, it may be helpful to ask the pastor about his motives and actions to better understand whether a true and

\footnotetext{
${ }^{24}$ C. 1530.

${ }^{25}$ Cc. $1531 \S 1$ and $1728 \S 2$. Cox, Craig A., "The Contentious Trial (cc. 1501-1670)" in New Commentary, ed. John P. Beal et al., 1671.

${ }^{26}$ C. $1531 \S \S 1$ and 2.
} 
lasting aversion exists in the parish. On the other hand, the delegate may be obligated to hear the pastor regarding a factual matter that must be established in the course of the instruction or regarding a detail that cannot be established without the pastor's testimony. For example, if a pastor is infirm, it may be necessary to inquire about the pastor's prescription medication and his medical prognosis. If a large amount of money is missing from the parish account, it may be necessary to question the pastor about this discrepancy in order to discover how the money was spent and whether or not the expenditure was legitimate.

When a pastor's testimony is being taken, he may voluntarily make a statement against his own interests or against his pastoral ministry. In a trial, a distinction is made between a judicial confession (a statement made against one's own interests before a judge concerning the matter of the trial) and an extra-judicial confession (any other statement made against one's own interests). ${ }^{27}$ Because the investigation in the removal of a pastor is part of an administrative procedure and not a judicial process, it is not proper to speak of a "judicial" versus "extra-judicial" confession in this context. Rather, an analogy may be drawn with a confession made in the context of the instruction (an "instructional" confession) and a confession made prior to the instruction (a "pre-instructional" confession). Even if no declaration is sought from the pastor in the course of the investigation, it is still very likely that some "pre-instructional" declaration of the pastor will be relevant to the case. Before a diocesan bishop begins the procedure to remove a pastor, it is probable, and in some

\footnotetext{
${ }^{27}$ C. 1535 . Cox, 1673.
} 
cases mandatory, that the bishop previously intervene before removing the pastor. ${ }^{28}$ Any declarations made by the pastor during this time, whether oral or written, may later be introduced into the acts in the cause for his removal. The diocesan bishop must weigh the probative value of these declarations, considering the time in which the pastor made the statement. If a pastor made one statement before his removal was contemplated (tempore non suspecto) and another statement in view of his possible removal (tempore suspecto), the diocesan bishop can give one statement greater probative value based on the circumstances of each statement. $^{29}$

\section{Proof through Documents (Cc. 1539-1546)}

Proof by means of documents is always permitted in any kind of trial, and may be useful in the procedure for the removal of a pastor. ${ }^{30}$ Documents may have varying levels of probative value. A public document, whether civil or ecclesiastical, is considered to be fully probative with respect to what it directly and principally affirms. Other documents, which are private, must be evaluated to determine their probative weight. The probative value of a document depends, in part, on its authenticity. $^{31}$

The delegate in a procedure for removal might collect several kinds of documents. Correspondence between the pastor and diocesan officials might be useful to establish that the diocesan bishop had warned a pastor about his violation or

\footnotetext{
${ }^{28}$ A warning is required before removing the pastor who neglects his parochial duties (see c. 1741, $4^{\circ}$ ). Another remedy must be sought before removing a pastor for poor administration (see c. $1741,5^{\circ}$ ).

${ }^{29}$ C. 1537 . Cox, 1673. A judge in a marriage case may give greater probative weight to documents written at a non-suspect time. See Dignitas Conubii, Art. $186 \S 1$.

${ }^{30}$ C. 1539

${ }^{31}$ Cc. 1541-1544. See also c. 1536 §2. Cox, 1675.
} 
negligence of his pastoral duties, or had proposed a solution to a pastor's poor financial administration. This correspondence might also indicate the pastor's physical condition, state of mind, or approach to parish difficulties, and thereby provide evidentiary support for one of the causes for removal. Any statements made by the pastor in his correspondence with diocesan officials have the force of proof of an extra-judicial (or "pre-instructional") confession. ${ }^{32}$

Correspondence from parishioners is valuable in evaluating any of the five causes for removal because the parishioners provide direct knowledge of problems through their regular participation in parish life. The diocesan bishop must weigh these letters to determine the validity of the parishioner's concerns, as the letters may be the result of a few disgruntled persons attempting to inflame a relatively insignificant problem. The authenticity of these documents determines their creditability, and so anonymous letters are of very little value because it is not possible to verify the information in the letter with its author. The delegate may find letters from parishioners most useful in providing him with a point of departure for his inquiry. The delegate will strengthen the case against the pastor if he can confirm the accusations in the letters through additional evidence.

Parish bulletins may be valuable in an inquiry into any of the five causes for removal. Any letters "From the Pastor's Desk" printed in the bulletin may indicate the pastor's approach to doctrine or Church authority and thereby demonstrate the pastor's disturbance of ecclesiastical communion. Announcements in the bulletin may give evidence of the pastor's failing mental or physical health. Defensive

${ }^{32}$ C. 1542 . 
responses from the pastor in the bulletin may be a sign of a growing aversion to his ministry. The bulletin may give evidence of a pastor's negligence or violation of his duties if he had been illegitimately absent from his parish, or if the pastor had regularly cancelled Masses, confessions, or other services. The bulletin may contain financial reports that can be used to demonstrate the pastor's poor administration.

The minutes of the parish pastoral council may testify to problems, such as a deterioration of parochial communion, a growing aversion to the pastor, or a dissatisfaction with the pastor's negligent service. The minutes of the parish finance council and other financial reports may demonstrate poor administration. These minutes and reports are useful, especially if they demonstrate that the pastor reported incorrect financial information, perhaps due to his incompetence or even due to his willful concealment of the parish's financial woes.

Other types of documentary proof may also be considered. Newspaper articles may indicate troublesome parish activities, tensions in a parish, or a pastor's scandalous conduct. Medical documents may provide proof of a pastor's poor physical or mental health. Legal documents may provide proof of harm to a parish caused by poor administration. The annual parish reports made to the diocese may provide evidence of a pattern of ineffective ministry.

Witnesses and Testimonies (Cc. 1547-1573)

The testimony of witnesses is allowed under the direction of the judge in any kind of case and may also provide valuable information in a procedure for removal. ${ }^{33}$ Anyone who can offer relevant testimony may serve as a witness unless they are

${ }^{33}$ C. 1547. 
excluded by law. ${ }^{34}$ These witnesses might include other clergy, and especially the vicar forane. ${ }^{35}$ The vicar forane may be a particularly useful witness because he is charged to exercise vigilance over the parishes in his vicariate, and has a responsibility of performing parish visitations. ${ }^{36}$ The vicar forane enjoys a high degree of credibility as a qualified witness when he testifies to those things done in performance of his duties. $^{37}$

The selection of some parishioners as witnesses will also be useful because, in many cases, the parishioners will be able to give the best testimony as first-hand witnesses to the ministry of their pastor. José María Díaz Moreno goes further to argue that parishioners have a right to be heard in cases involving the removal of their pastor. $^{38}$ However, the taking of testimony from parishioners may still be problematic. A parishioner might be unwilling to give testimony against his or her

${ }^{34}$ C. 1549 . Clerics and other officials who are bound by professional secrecy are exempt from testifying (c. $1548 \S 2,1^{\circ}$ ). Those under the age of fourteen are generally not permitted to testify (c. $1550 \S 1$ ). No information learned from the confessional can be admitted as testimony (c. $1550 \S 2,2^{\circ}$ ).

${ }^{35}$ Romita, 439. Parizek, 1040. Romita notes that Ecclesiae Sanctae encourages a diocesan bishop to hear the vicar forane in the case of the removal of a pastor. See Paul VI, motu proprio Ecclesiae Sanctae I 19 §2, August 6, 1966, AAS 58 (1966) 769. The advisory role of the vicar forane in the bishop's appointment of a pastor was mentioned earlier in this chapter (see c. 524).

${ }^{36}$ A vicar forane has a duty and a right to coordinate pastoral activities in his vicariate, to see that clerics perform their duties diligently, and to see that discipline is observed in liturgical and temporal affairs (c. $555 \S 1$ ). The vicar forane may be involved in helping a pastor deal with problems in his parish (c. $555 \S 2,2^{\circ}$ ). The vicar forane has an obligation to visit the parishes in his vicariate (c. 555 $\S 4)$. Each of these duties make the vicar forane an ideal witness to testify to the ministry of the pastor.

${ }^{37}$ C. 1573 .

${ }^{38}$ José María Díaz Moreno, "Derechos de los fieles y vida parroquial" in La Parroquia desde el Nuevo Derecho Canonico, ed. Julio Manzanares (Salamanca: Universidad Pontificia, 1991) 151. The code admits the possibility that the diocesan bishop may wish to consult with lay persons before the appointment of a pastor (c. 524). Moreno argues that this language should be stronger as the faithful have a right to make known their needs and opinions to the pastors of the Church (c. $212 \S \S 2$ and 3). Because a pastor may only be removed for harmful or ineffective ministry, Moreno argues that the faithful who suffer from the poor ministry should have the right to make known their opinion of their pastor in a procedure for his removal. Moreno suggests that the investigation for the removal of a pastor should at least consult the parish pastoral council mentioned in canon 536. Coccopalmerio also mentions consultation with the parish pastoral council, though only in the context of the appointment of the pastor. See Coccopalmerio, De Paroecia, 120. 
pastor because of a fear of retribution from the pastor, or of rejection by fellow parishioners. A parishioner with these anxieties may not wish to testify. ${ }^{39}$ When examining parishioners, the delegate must exercise great caution to avoid injuring the good name of the pastor. ${ }^{40}$ To this end, the delegate should carefully pose questions that are "not deceitful or deceptive or suggestive of a response, free from any kind of offense, and pertinent to the case being tried. ${ }^{41}$ The delegate can inquire about the parishioner's perception of the pastor, but any criticism of the pastor should arise from the parishioner's free response and not from any bias in the delegate's questions.

The choice of parishioners to serve as witnesses is another difficulty. The delegate can limit the number of witnesses and certainly does not need to hear every parishioner. ${ }^{42} \mathrm{He}$ may choose parishioners because of their longstanding membership in the parish, their prudence, their roles of leadership, or their knowledge of the cause for removal. The delegate may select some members of the pastoral council or finance council, the chairpersons of parish committees, or the coordinators of various ministries in the parish or parochial school. The delegate may also select some parishioners who have written letters to the diocese about the pastor's ministry.

In a trial, the parties themselves have a right to introduce witnesses, be informed of the list of witnesses, and object to a witness. ${ }^{43}$ If the pastor is aware that an instruction has been initiated, he may raise his objections which the delegate

\footnotetext{
${ }^{39}$ C. $1548 \S 2,2^{\circ}$. Witnesses are exempted from testifying in a trial when they believe their testimony will cause them or their relatives to suffer ill repute, dangerous hardships, or other grave evils.

${ }^{40}$ See c. $1717 \S 3$.

${ }^{41}$ C. 1564: "[Interrogationes sunto]. . . non captiosae, non subdolae, non suggerentes responsionem, remotae a cuiusvis offensione et pertinentes ad causam quae agitur."

${ }^{42}$ C. 1553 .

${ }^{43}$ Cc. 1551, 1554, and 1555 .
} 
should decide fairly and as quickly as possible (expeditissime). The decision of the delegate does not admit of appeal. If the pastor is unaware of the instruction, he may raise his concerns and introduce statements from his own witnesses when he submits his written report after the delegate has completed his instruction. ${ }^{44}$ If the pastor believes that his right to defend his ministry has been denied, he should include his arguments in his written report and in any petition for subsequent hierarchical recourse.

The delegate should establish the identity and the credibility of each witness. If the witness is a parishioner, he may ask about the parishioner's length of membership in the parish, knowledge of the parish, and level of voluntary participation in the life and activities of the parish. ${ }^{45}$ The testimony of a witness is more trustworthy if he or she possesses a good reputation, or is chosen because of an official position that he or she holds. ${ }^{46}$ In the case of removal due to the loss of the pastor's good reputation, the delegate must verify that any parishioner who is heard is also upright and responsible (probus et gravis) in forming judgments. ${ }^{47}$

The delegate chooses the location to hear the witnesses. ${ }^{48}$ Therefore, the delegate may hear the witnesses at his or her parish because of its convenient location, even if the pastor objects to this proposal. The delegate may take testimony

\footnotetext{
${ }^{44}$ Canon $1745,1^{\circ}$ only gives the pastor the right to submit a written report. If the delegate rejects any witnesses proposed by the pastor, the pastor may nevertheless include statements from his witnesses in his written report. The 1917 code anticipated that the pastor might ask that some witnesses be heard, although the ordinary was not bound to hear them (CIC 1917, c. $2145 \S 1)$.

${ }^{45}$ C. 1563 . The delegate is to establish the identity of the witness, and inquire about the relationship of the witness to the pastor.

${ }^{46}$ C. $1572,1^{\circ}$. Cox, 1690.

${ }^{47}$ C. $1741,3^{\circ}$.

${ }^{48}$ C. $1558 \S \S 1$ and 3.
} 
in the context of a pastoral visitation of the parish, although he must guard against harming the pastor's good name and should avoid creating a cloud of suspicion over the pastor through his instruction of the case. ${ }^{49}$ The pastor does not have a right to be present when the witnesses are examined. ${ }^{50}$ If possible, the delegate should have a notary present when taking testimony. ${ }^{51}$ The witnesses should not bring in notes unless they are necessary, such as in the case of a witness who is questioned about poor administration and must have financial reports available in order to testify. ${ }^{52}$ The delegate should inquire about the pastor's words, actions, and inactions in the parish. He should inquire about the circumstances, the source of the witness's knowledge, and the time that these events occurred. ${ }^{53}$

\section{Experts (Cc. 1574-1581)}

The testimony of experts may be useful in a trial and is required in certain cases of incapacity to contract marriage. ${ }^{54}$ The delegate may likewise determine that the use of an expert is needed in a specific cause for removal. If the delegate appoints an expert, he determines the matters the expert is to examine. ${ }^{55}$ In a trial, the parties have a right to be informed of the use of an expert, object to the selection of an

\footnotetext{
${ }^{49}$ Grocholewski, 223. The diocesan bishop has the obligation of visiting his parishes, which can be done through another presbyter (c. $396 \S 1$ ). If the diocesan bishop judges this to be a prudent way to assess the ministry of the pastor in question, he may appoint the delegate or another priest to conduct a parish visitation. The appointment of the delegate to conduct a pastoral visitation is separate from his appointment to instruct the cause for removal.

${ }^{50}$ C. 1559.

${ }^{51}$ C. 1561 . A notary was explicitly required under the 1917 code (CIC 1917, c. 2142).

${ }^{52}$ C. 1566.

${ }^{53}$ C. 1563 .

${ }^{54}$ C. 1574. Dignitas Conubii, Art. 203.

${ }^{55}$ Cc. 1574 and $1577 \S 1$.
} 
expert, and designate their own experts. ${ }^{56}$ If the pastor is aware that an instruction has been initiated, he may raise his objections during the instruction which should be settled by the delegate expeditissime. If the pastor is unaware of the instruction, he may raise his objections and introduce statements from his own experts when he submits his written report after the instruction is completed. ${ }^{57}$

There are several possible circumstances in which an expert would be useful in a procedure for removal. If the cause for removal is a disturbance of ecclesiastical communion, a theological expert may be helpful in determining whether a pastor's teachings are consonant with the teachings of the Church. If the pastor is inept or infirm, a doctor or psychiatrist may testify to the pastor's physical or mental health and his ability to fulfill his pastoral duties. If there is an aversion to the pastor, a psychologist may offer testimony about the cause or the validity of the aversion. If a pastor has shown poor administration in temporal affairs, an accountant might examine the financial records of the parish, or a civil lawyer might offer an opinion about the legal liability to the Church from the pastor's actions.

\section{Judicial Examination and Inspection (Cc. 1582-1583)}

Like a judge in a trial, the delegate may visit a place or inspect an object, if it is useful. As noted above, the diocesan bishop can appoint the delegate to conduct a pastoral visitation of the parish. However, in the context of the removal of a pastor,

\footnotetext{
${ }^{56}$ Cc. 1575,1576 , and $1581 \S 1$.

${ }^{57}$ C. $1745,1^{\circ}$. In footnote 44 , it was observed that the pastor can submit witness statements in his written report. Similarly, if the delegate refuses to hear an expert designated by the pastor, the pastor can still include statements from his own experts in his written report if it is appropriate. An expert appointed by the delegate may be allowed to view the acts of the case before giving his report. However, when preparing his defense, only the pastor and his advocate have the right to review the acts in the procedure for his removal. An expert designated by the pastor but not accepted by the delegate cannot claim the right to inspect the acts.
} 
the visitation described in canons 1582 and 1583 is not pastoral but rather for the sake of gathering proofs related to the cause for removal. Under these canons, the delegate can visit a place or inspect an object in order to gather evidence for his report. The delegate may require by decree that certain items be made available for his inspection. $^{58}$

The delegate may wish to visit the parish to inspect a variety of things. He may inspect the parish bulletins for the reasons given under documentary proofs. $\mathrm{He}$ may inspect the financial records of the parish in a case of poor administration. $\mathrm{He}$ may inspect the sacramental books or the record of Mass stipends if this inspection could demonstrate that the pastor has violated or neglected his sacramental duties. ${ }^{59}$ If an aversion to the pastor is due to an imprudent building project, such as an overly elaborate expansion or improvement of the rectory, the delegate may wish to examine the project.

\section{Presumptions (Cc. 1584-1586)}

A presumption is a probable conjecture about something that is unknown. Presumptions are legal if they are established in the law, and human if they are formulated by the judge. ${ }^{60}$ Presumptions are not proofs properly speaking, but they are useful as an indispensable tool that allows a judge to reach moral certitude in a trial. In this sense, presumptions can constitute "an 'indirect' rather than a direct form of proof."61

\footnotetext{
${ }^{58}$ C. 1582 . See Cox, 1697.

${ }^{59}$ The inspection of the parochial registers is one of the duties of the vicar forane (c. $555 \S 1,3^{\circ}$ ).

${ }^{60}$ C. 1584.

${ }^{61}$ Cox, 1697.
} 
There are no explicit legal presumptions in the code relevant to the removal of the pastor, although a legal presumption may be inferred from some of the canons. Pastors must possess stability as a characteristic of their office defined by law. ${ }^{62}$ Because he possesses stability, the pastor has a right to continue in office until he loses his office in accord with the norm of law. The bias of the law favors the pastor remaining in office when there is doubt about his harmful or ineffective ministry. Therefore, as a corollary to the stability of the pastor, there is a presumption implicit in the law that a pastor's ministry is useful. This presumption can admit of contrary proof that the pastor's ministry is harmful or ineffective. ${ }^{63}$ This implicit presumption is strengthened by the fact that the pastor was judged to be suitable for his parish at the time he was appointed. ${ }^{64}$

The diocesan bishop may formulate other human presumptions when judging the pastor's ministry. For example, under the third cause of aversion to the pastor, the diocesan bishop may presume that aversion is present if some members of the faithful withdraw from the life of their parish, fail to attend Mass, refuse to confess to their pastor, or neglect to present their children for baptism or for catechetical instruction. ${ }^{65}$ The use of a human presumption may help the diocesan bishop conclude from individual signs of aversion that the pastor's ministry has become gravely harmful or ineffective. The diocesan bishop may presume that aversion will not quickly cease if

\footnotetext{
${ }^{62}$ C. 522. Romita, 437.

${ }^{63}$ Cox, 1697.

${ }^{64}$ Cc. $521 \S 3$ and 524. When the diocesan bishop appoints a pastor, he must judge the priest to be suitable not only for the office of pastor (c. $521 \S 3$ ), but also suited to the needs of the parish to which he is appointed (c. 524).

${ }^{65}$ de Sancristóval, 409.
} 
the negative reactions of the parishioners remain consistent or steadily grow over a specific period of time. Under the fourth cause of violation or neglect of pastoral duties, the bishop may presume that a pastor persists in his neglect if his behavior after a warning has not changed or has become worse over a specific period of time. Under the fifth cause of poor financial administration, the bishop may presume that no other solution may be found to a pastor's poor administration if the pastor rejects a remedy offered by the bishop, or if a remedy is implemented but does not solve the problem.

\section{The Purpose of the Proofs}

The delegate in the instruction of a cause for removal must proceed very carefully with the collection of proofs. He should consider several important values as he proceeds. The delegate should focus first of all on proofs that are useful and necessary to construct a case for removal. ${ }^{66}$ Proofs are not useful unless they demonstrate the harmful or ineffective ministry of the pastor. Second, the delegate must carefully avoid harming the good name of the pastor being investigated. This fundamental requirement of justice demands that the delegate proceed delicately. Third, he should collect sufficient proof to demonstrate the pastor's detrimental ministry. By remembering the standard for removal, the delegate should not fail to gather adequate proof lest the cause for removal remain in doubt. Neither should the delegate gather excessive proofs, as unnecessary probing may not help the instruction, but only serve to amplify the sense of mistrust or skepticism on the part of the parishioners. A delegate who discharges his duties with care, diligence, and

\footnotetext{
${ }^{66}$ Canon 1527 permits the collection of any type of proof in a case, provided it is useful.
} 
prudence works ultimately for the good of souls. His judicious instruction may avoid an injustice if he can demonstrate that the removal of the pastor is not warranted. On the other hand, when removal is warranted, the careful collection of proofs may not only demonstrate that the pastor should be removed, but may even help the pastor to accept this fact. 


\section{Conclusion}

When the ministry of a pastor has become harmful or ineffective, the faithful suffer, but so too does the pastor, whose efforts are frustrated by the cause of his negative ministry. Even if the pastor it not to blame for his detrimental ministry, it is not good for a pastor to continue to be constrained in a position of failing leadership. It has been observed that the procedure for removal looks to the good of souls, but the good of the pastor is also at stake. It is possible that the removal of a pastor may even look to his good if his ministry is truly inadequate or harmful. A pastor may be reticent to accept this possibility, but the good of the pastor must also enter into the mind of the diocesan bishop when making a decision for removal. It should always be hoped that the procedure for removal may bring a positive result even from a disheartening and unfortunate situation.

The procedure for removal must be well instructed; the collection of proofs must clearly demonstrate the cause for removal; and the harmful or ineffective ministry of the pastor must be proven. If a case is poorly instructed, a pastor may feel, with some justification, that his rights have been violated. If a cause is insufficiently proven, a pastor may have reason to believe that he is being railroaded by his bishop who lacks genuine concern for him as a priest-son. Conversely, as difficult as it is to face, a pastor may be more readily inclined to accept the judgment of his bishop if he sees the clear evidence of his inadequate ministry, and knows that 
the procedure has been executed in an evenhanded and just way. If the pastor's ministry has been proven to be gravely deficient, the best resolution occurs if the pastor steps down from his office for the good of his parish, and even for his own personal good.

At the beginning of this thesis, an analogy was drawn between the ministry of the pastor to his parish and the marital bond. The removal of a pastor from his parish can have all the painful characteristics of a separation and a divorce. However, many individuals move past the pain of a broken marriage to seek an annulment. The examination of a marriage in a nullity case can be distressing and hard to endure, but this process can also be helpful and even enlightening to the parties as they cope with a failed marriage and learn from their past mistakes. While the procedure for the removal of a pastor is also difficult, it may also yield a positive result if it is conducted well and with pastoral sensitivity to the parishioners and the pastor involved. The diocesan bishop is to care for his people and is to paternally attend to his presbyterate, even in this procedure for removal. The firm but gentle hand of the shepherd in dealing with these difficult situations will lead to the greatest hope of an ultimately positive outcome. 


\section{Bibliography}

\section{$\underline{\text { Primary Sources }}$}

Code of Canon Law, Latin-English Edition: New English Translation. Washington, DC: Canon Law Society of America, 1998.

Codex Iuris Canonici auctoritate Ioannis Pauli PP. II promulgatus. Vatican City: Libreria Editrice Vaticana, 1983.

Codex Iuris Canonici Pii X Pontificis Maximi iussu digestus Benedicti Papae XV auctoritate promulgatus. Rome: Typis Polyglottis Vaticanis, 1917.

John Paul II. Apostolic Letter Sacramentorum Sanctitatis Tutela, 30 April 2001. Acta Apostolica Sedis (AAS) 93 (2001) 737-739.

Paul VI. Motu Proprio Ecclesiae Sanctae, 6 August 1966. AAS 58 (1966) 757-787.

Pontifical Council for Legislative Texts. Instruction Dignitas Conubii. Vatican City: Libreria Editrice Vaticana, 2005.

Sacred Congregation of the Consistory. Decree Maxima Cura, 20 August 1910. AAS 2 (1910) 636-648.

Vatican Council II. Decree Christus Dominus, 28 October 1965. AAS 58 (1966) 673696. (1965) 1-67.

United States Conference of Catholic Bishops. Decree Essential Norms for Diocesan/Eparchial Policies Dealing with Allegations of Sexual Abuse of Minors by Priests or Deacons, 5 May 2006. Washington, DC: USCCB, 2006.

\section{$\underline{\text { Secondary Sources }}$}

Beal, John P., Coriden, James A., Green, Thomas J., eds. New Commentary on the Code of Canon Law (hereafter New Commentary). New York/Mahwah, NJ: Paulist Press, 2000.

Coccopalmerio, Francesco. "De Causis ad Amotionem Parochorum Requisitis." Periodica 75 (1986) 273-302. . De Paroecia. Rome: Pontificia Università Gregoriana, 1991.

Coriden, James A., Green, Thomas J., Heintschel, Donald E., eds. The Code of Canon Law: A Text and Commentary (hereafter Text and Commentary). New York/Mahwah, NJ: Paulist Press, 1985. 
Cox, Craig A. "The Contentious Trial (cc. 1501-1670)." In New Commentary, ed. John P. Beal et al., 1655-1759.

Cusack, Barbara Anne. "The Internal Ordering of Particular Churches (cc. 460572)." In New Commentary, ed. John P. Beal et al., 610-740.

Daneels, Frans. "The Removal or Transfer of a Pastor in the Light of the Jurisprudence of the Apostolic Signatura." Forum 8:2 (1997) 295-301.

de Sancristóval y Murúa, M. "El 'Odium Plebis' como Causa de Remoción del Parroco.” Ius Canonicum 1 (1961) 351-414.

Grocholewski, Zenon. "Trasferimento e rimozione del parroco." In La Parrocchia. Studi Giuridici, vol. 43, 199-247. Vatican City: Libreria Editrice Vaticana, 1997.

Janicki, Joseph A. "Chapter VI: Parishes, Pastors, and Parochial Vicars (cc. 515552)." In Text and Commentary, ed. James A. Coriden et al., 414-440.

Marzoa, Ángel. "Sectio II: De procedura in parochis amovendis vel transferendis (cc. 1740-1752)." In Exegetical Commentary on the Code of Canon Law, ed. Ángel Marzoa, Jorge Miras, and Rafael Rodríguez-Ocaña, IV/2:2099-2148. Chicago: Midwest Theological Forum, 2004.

Moreno, José María Díaz. "Derechos de los fieles y vida parroquial." In $L a$ Parroquia desde el Nuevo Derecho Canonico, ed. Julio Manzanares, 117-160. Salamanca: Universidad Pontificia, 1991.

Morgante, Marcello. La Parrocchia nel Codice del Diritto Canonico: Commento giuridico-pastorale. Milan: Edizione Pauline, 1985.

Paprocki, Thomas J. "The Method of Proceeding in Administrative Recourse and in the Removal or Transfer of Pastors (cc. 1732-1752)." In New Commentary, ed. John P. Beal et al., 1818-1852.

Parizek, James F. "Section II: Procedure in Removal and Transfer of Pastors (cc. 1740-1752)." In Text and Commentary, ed. James A. Coriden et al., 10351045.

Romita, Florentius. "De Parochorum Amotione, Translatione et Renuntiatione juxta Vaticanum II." Monitor Ecclesiasticus 94 (1969) 430-450.

Sweeney, Edward A. The Obligations and Rights of the Pastor of a Parish According to the Code of Canon Law. Ottawa: Alba House, 2002. 

